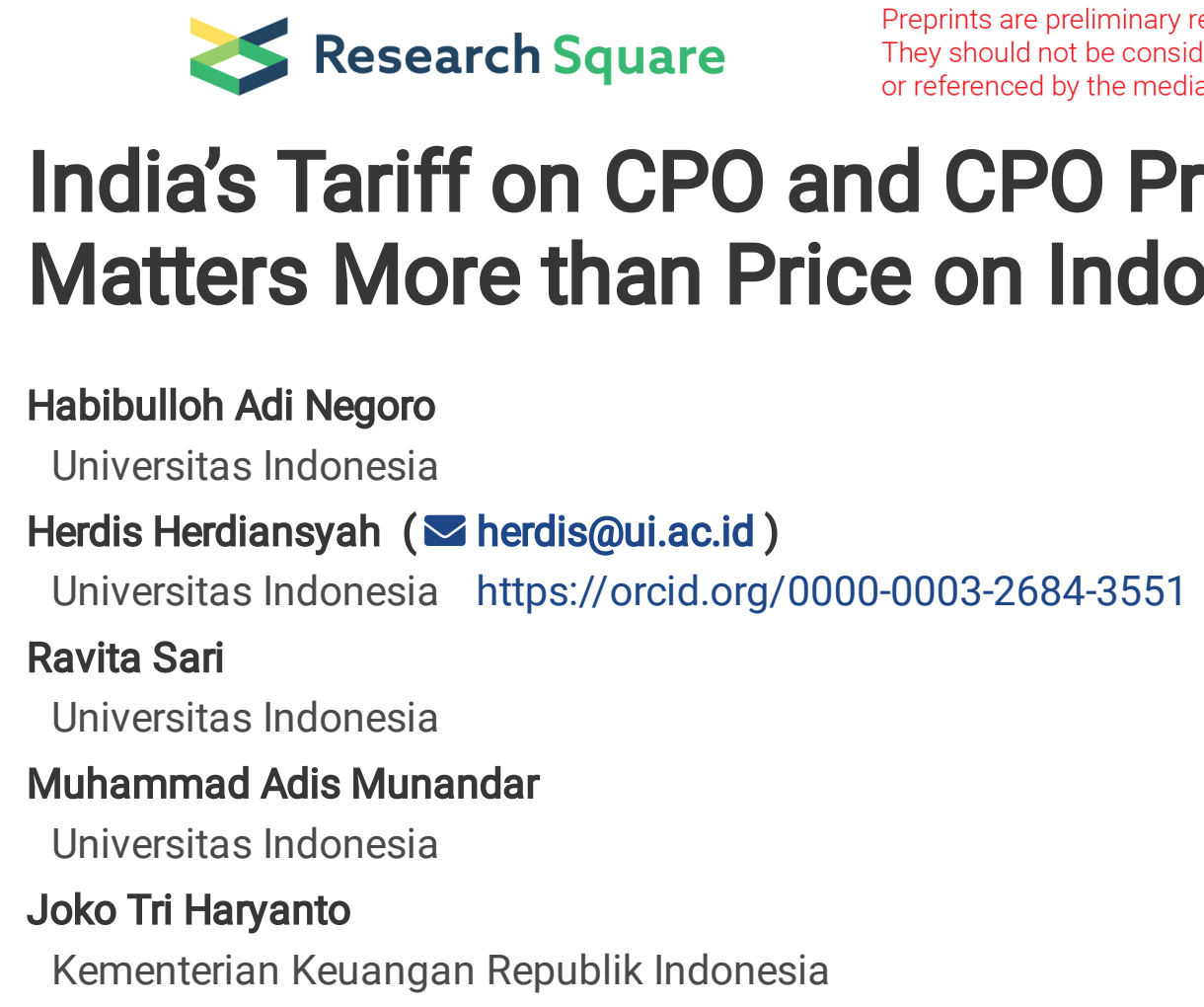

\author{
Habibulloh Adi Negoro \\ Universitas Indonesia \\ Herdis Herdiansyah ( $\nabla$ herdis@ui.ac.id ) \\ Universitas Indonesia https://orcid.org/0000-0003-2684-3551 \\ Ravita Sari \\ Universitas Indonesia \\ Muhammad Adis Munandar \\ Universitas Indonesia \\ Joko Tri Haryanto \\ Kementerian Keuangan Republik Indonesia
}

\title{
India's Tariff on CPO and CPO Price: Why Tariff Matters More than Price on Indonesia's CPO
}

\section{Research}

Keywords: export tariff, crude palm oil, export commodity

Posted Date: August 12th, 2020

DOI: https://doi.org/10.21203/rs.3.rs-56132/v1

License: (c) (i) This work is licensed under a Creative Commons Attribution 4.0 International License.

Read Full License 
1 India's Tariff on CPO and CPO Price: Why Tariff Matters More than Price on

2 Indonesia's CPO

3

4 Habibulloh Adi Negoro ${ }^{1}$, Herdis Herdiansyah ${ }^{2, *}$, Ravita Sari ${ }^{2}$, Muhammad Adis Munandar ${ }^{3}$, 5 Joko Tri Haryanto ${ }^{4}$

$6{ }^{1}$ Faculty of Business and Economic, Universitas Indonesia, Depok, West Java 16424, $7 \quad$ Indonesia

$8{ }^{2}$ School of Environmental Science, Universitas Indonesia, Central Jakarta, DKI Jakarta 9 10430, Indonesia

$10{ }^{3}$ School of Strategic and Global Studies, Universitas Indonesia, Central Jakarta, DKI Jakarta 11 10430, Indonesia

$12{ }^{4}$ Fiscal Policy Agency, Ministry of Finance, Indonesia

\section{Declarations}

15 Availability of data and materials: All data generated or analysed during this study are 16 included in this published article [and its supplementary information files].

17 Competing interests: The authors declare that they have no competing interests.

18 Funding: This work was supported by the Universitas Indonesia under International 19 Research Collaboration Grant 2019 [number NKB-1959/UN2.R3.1/HKP.05.00/2019].

20 Authors' contributions: HAN calculated, analyzed, and interpreted data gathered from BPS,

21 Bloomberg, and Bank Indonesia Statistics. HAN also produced graphs and tables displayed 22 in this article. HH designed the research and discussed the results. RS, MAM, and JTH 23 conducted literature review and discussed the results. All authors read and approved the final 24 manuscript. 
Acknowledgements: The authors extend sincere gratitude to Dr. Stefanie Steinebach from

HAWK-HHG (Hochschule für angewandte Wissenschaft und Kunst-

Hildesheim/Holzminden/Göttingen), who becomes an international collaborative research partner.

\section{Abstract}

31 Palm oil and its derivatives are one of Indonesia's prominent export commodities on the global market. India is one of the main biggest export destinations of Indonesia's CPO, thus every trade policy taken by India regarding CPO is important to Indonesia's trade balance. This study has found that tariff imposed by India on Indonesia's CPO has an elastic relationship compared to the $\mathrm{CPO}$ price. Moreover, this study found that changes in tariff are likely to significantly affect Indonesia's CPO export to India, compared to CPO price. Increase in price does not affect Indonesia's CPO export to India since it has inelastic relationship; as such the percentage of change in quantity does not exceed the change of price percentage.

40 Keywords: export tariff, crude palm oil, export commodity.

\section{Introduction}

The growing population and wealth have urged the demand for oils and fats

worldwide. The consequence was indicated as a significant increase in global consumption of oils and fat (Santika et al. 2019). Palm oil is one of several commodities that has been traded globally and contributed around $34 \%$ of vegetable oil production worldwide. Soybean oil is

47 known as palm oil's biggest competitor, which contributed around 29\% (United States Department of Agriculture 2017) - followed by Rapeseed oil and Sunflower oil. The benefits of this oil are effectively interchangeable for edible downstream products such as snacks, 
sweets, margarine, baked goods, cereals, etc. as well as non-edible products such as detergents, soap, cosmetics, and biofuel (Corley 2009; Wilman 2019).

The increasing global demand for palm oil utilisation in energy, food, cosmetics, and other industrial processes impacts to the escalation of palm oil production demand (Purnomo et al. 2020). The implication of palm oil demand was reflected in the rise of its global production from 14 million tonnes in 1993 to 71 million tonnes in 2018 (Faostat 2020). Over the last two decades, the area palm oil plantations has significantly escalated globally from 6 to 18 million hectares. It has an account of around $0.4 \%$ of the permanent cropland worldwide (Santika et al. 2019). Palm oil trees can be cultivated on areas of former humid tropical forests, and it can also grow on burned and drained peatlands. Before 2000, palm oil

60 plantations were mostly developed either on barren land, burnt-over areas, or on existing farmland. However, the conversion from forest to plantation areas becomes a common practice nowadays due to scarcity of non-forest land for agriculture purposes. The conversion practice from forests to plantations can be a potential hazard for biodiversity and the escalation of greenhouse gas emissions (Mukherjee and Sovacool 2014; Potter 2015; Santika et al. 2019).

Therefore, palm oil has a huge contribution to both economic development and environmental degradation. It has become an exceptionally debated topic among researchers. Indonesia and Malaysia are the world's top exporters of palm oil, which provide approximately 56\% and 35\% of all palm oil exports (United States Department of Agriculture 2017). Meanwhile, India, the European Union (EU) and China are the top three importers of palm oil, with $20 \%, 15 \%$ and $10 \%$ of palm oil imports, respectively. The oil palm industry has been proven to be one of the most important industries for both Malaysia and Indonesia. Palm oil contributes significantly to national development in Indonesia. The growth of palm oil industry has increased rapidly, with the plantation expansion from 1990 to 2005 
recorded at more than $12 \%$ annually. As of 2010, the total palm oil plantation in Indonesia was around 7.82 million hectares. Most of the oil palm plantations (more than $60 \%$ ) were located in Sumatera, Kalimantan, and Sulawesi. The major privately-owned palm oil producers in Indonesia are PT. Astra Agro Lestari TBK, PT. Perusahaan Perkebunan London Sumatra Indonesia TBK, PT. Sinar Mas Agro Resources and Technology TBK, and PT. Bakrie Sumatera Plantation TBK (Hashim et al. 2012).

The export value of palm oil exceeded USD 23 billion in 2017, and it was recorded to contribute to $17 \%$ of Indonesia's agricultural gross domestic product in 2014 (Tim Riset PASPI 2018). Due to the importance of palm oil commodities, government of Indonesia has established several targets in regards to the production and productivity of palm oil commodities. In the early 2010 s, palm oil production has targeted to reach 40 million tons of crude palm oil by 2020. As for productivity, the target is termed as 'Vision 35:26'. With the 'Vision 35:26' means the government encourages palm plantation to generate 35 tons per hectare (ha) of fresh fruit bunches (FFBs) from palm trees with a $26 \%$ oil extraction rate. However, the target is unlikely achieveable without expanding the palm plantation area.

90 Thus, the government proposed several incentives to meet the targets such as providing support to the private sector in terms of accessing and expanding their plantations. The palm oil plantations expansion aimed to boost Indonesia's economic growth for over 5\% in 2017-

932018 (MoA 2013; MoA 2016). The distribution of palm oil plantation and production are

94 shown in Figure 1. 


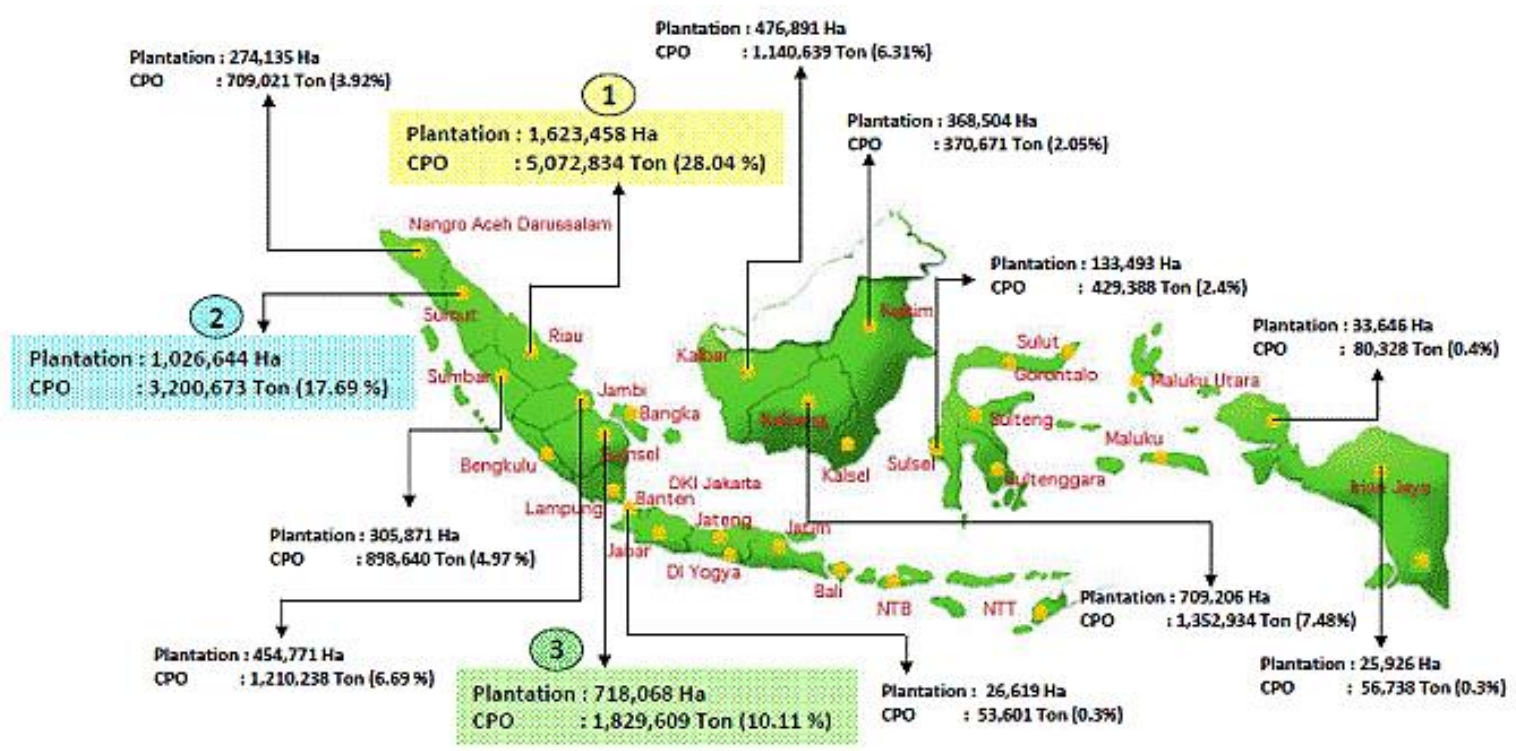

Figure 1. Distribution of Palm Oil Plantation and Production in Indonesia (InfoSawit 2020)

Tariffs are defined as customs duties which collected from the imported goods on a specific basis (fixed charge per unit of import, such as a kilogram/pounds, gallon, tons, or 100 others) or on ad valorem basis (fixed percentage of the value from the imported goods) 101 (Suranovic 2010). Most theoretical analyses of trade policy are carried out in terms of tariffs as duties collected on import activities due to: (i) tariff is a single device applied worldwide to control

104 trade flows, (ii) tariff is the only measurement of trade regulation permitted by General

105 Agreement on Tariffs and Trade (GATT) - in exception of special circumstances, (iii) tariff is determined by the price mechanism which reflects the modern economic theory (Robertson 1972).

During the first decade after 1945, quota restrictions and exchange controls were

109 respected as the main barriers that operated by the countries in Western Europe. Meanwhile,

110 tariffs were not considered as the most important barrier to international trade. Tariff was

111 designed as a punishment for foreign producers and domestic consumers of the taxed

112 commodity. It was created to support domestic producers and the government. The burden of 
113 a tariff will raise the domestic price of the taxed commodity and induce a reduction in the

114 demand of the imported commodity. Thus, the intention of a tariff was to promote domestic

115 output of the protected goods as well as to reduce domestic consumption using higher prices

116 mechanism.

117 According to Greenaway (1983), tariffs were divided into import tariff and export

118 tariff. Export tariff tends to be collected for revenue purposes, while import tariff tends to be

119 collected for protective purposes - export tariffs commonly applied in less developed

120 countries (LDCs) than developed market economies (DMEs). Tariffs can be seen as a source

121 to gain revenue as well, and this instrument is widely implemented in both LDCs and DMEs

122 (Greenaway, 1983). While the imposed tariff may not affect the trade of the small open

123 economy, the large open economy is a different story. Therefore, the tariff-imposing

124 countries enjoy some control elements of market power. However, unrestricted trade emerges

125 to be consistent with the higher level of economic welfare compared to the restricted trade,

126 unless the countries can apply an optimum tariff to prevent such unfavorable situation. In

127 case of a tariff increase, it can influence consumer behavior due to the change in the final

128 price of the imported good and its substitute (Greenaway 1983). This is consistent with the

129 Partial Equilibrium Effect theory, as shown in Figure 2. 


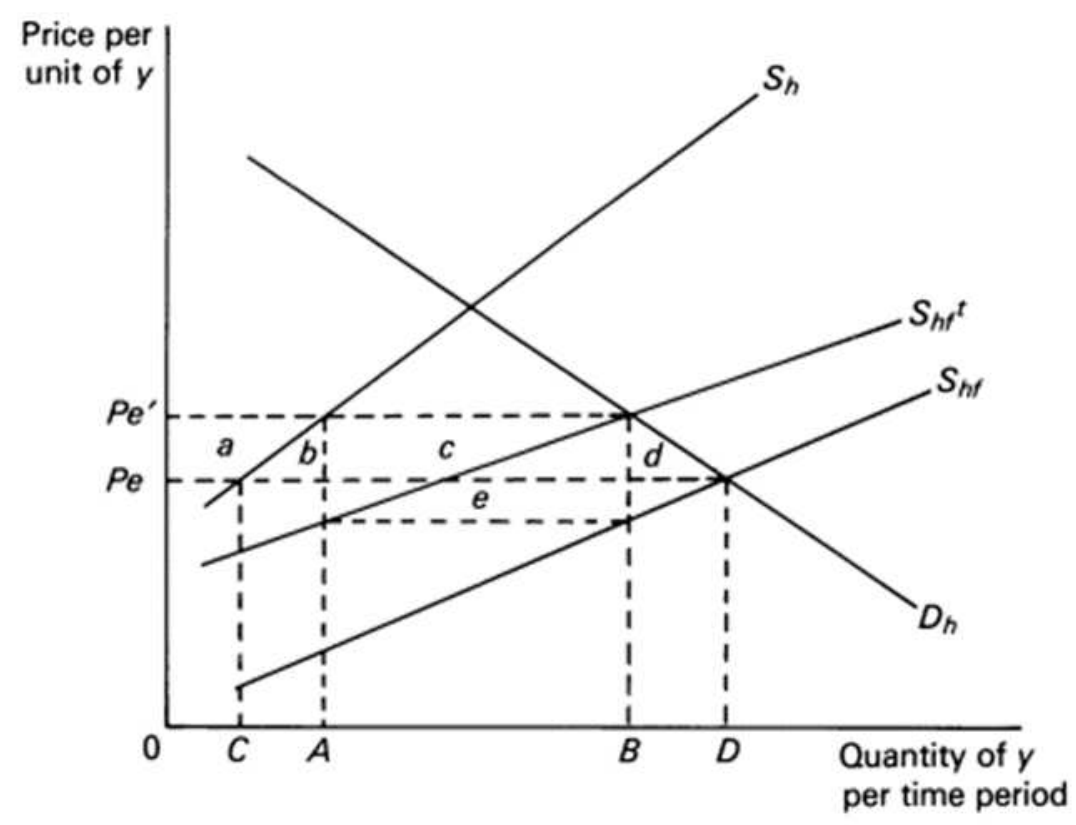

130

Figure 2. Partial Equilibrium Effect of a Tariff in a Country (Greenaway 1983)

Figure 2. Partial Equilibrium Effect of a Tariff in a Country (Greenaway 1983)

132 Notes:

$133 y$ : a substitute for imported commodity

$134 D_{h}$ : country's demand for commodity $y$

$135 S_{h}$ : country's supply of commodity $y$

$136 S_{h f}$ : total market supply (domestic supply + imports)

$137 S_{h f}{ }^{t}$ : supply of a tariff-distorted market

$138 P e$ : the domestic market price of $y$ without tariff burden

$139 P e^{\prime}:$ the domestic market price of $y$ with a nominal tariff rate of $t$ on all imported $y$

Figure 2 outlined a partial equilibrium effect in the case of a large country. $S_{h f}$ stands

142 below $S_{h}$ considering the pre-trade factor endowment, foreign producers produced

143 commodity $y$ at lower unit costs compared to domestic producers. OB is the market-clearing

144 quantity of $y, \mathrm{OA}$ is supplied by domestic producers, and $\mathrm{AB}$ was imported, while OD is the

145 expansion of demand when the tariff is removed. In the new equilibrium, domestic producers

146 provide OC rather than OA, which means that they supplied a smaller and lesser fragment of 
147 the market. When tariff liberalization is introduced, the import penetration rises from $\mathrm{AB} / \mathrm{OB}$

148 to CD/OD. These changes encourage rise to a number of effects, namely (Greenaway 1983):

149 Static effects (production, consumption, revenue, balance-of-payment, terms-of-trade) and

150 Dynamic effects (economies of scale and efficiency).

$151 \quad$ Static effects include:

152 a. Production effect takes place when fewer units are supplied by inefficient domestic

153 producers; thus, there is no misallocation loss of the resource-related aspect with the

154 tariff (the triangular area b).

155 b. Consumption effect happens when the existing costumers purchase commodity $y$ at a 156 lower price, therefore generating a net gain in customer surplus (the triangular area d).

c. Revenue effect develops when there is tariff liberalisation as indicated in vanished $\mathrm{e}+\mathrm{c}$ in Figure 2 . However, if the revenue from a tariff disappears and government expenditure has to be supported, the country will allow revenue from alternative sources such as increases in expenditure taxes, income tax, etc.

d. The balance-of-payments effect has been considered as an implicit barter model that has no meaning and tends to be ignored. However, unilateral trade liberalisation may generate a tendency towards payments deficit when trade flows are balanced by opposite monetary flows. This deficit has to be corrected by allowing some regulations (e.g. devaluation or deflation).

e. The terms-of-trade effect occurs when there is unilateral tariff liberalisation to generate 167 an unfavorable change in the international terms of trade and followed by a fall in real 168 income. It is represented by area of $\mathrm{c}$ in Figure 2, and such losses may have to be compensated by positive gains from production and consumption effects. 
a. Economy of scale is considered to be consistently increased with opportunities due to trade liberalisation and larger production that aim to reduce the unit cost of $y$. However, it is often argued that when such reductions are introduced towards the consumers, there would be parallel gains from production and consumption effects as price drops below Pe.

b. The efficiency is obtained as a result of an expanded market and increase competition, which in turn leads to a rise in efficiency. Further, it causes falls in unit costs of $y$ and/or better quality products.

181 leakage on market redirection to non-tariffed markets. It was also reported that an output subsidy can be an option to lower potential leakage from tariffed to non-tariffed markets. However, it may not work effectively in case of reducing unsustainable production when the transaction costs become a barrier for unsustainable producers to switch into sustainable producers. When the transaction costs can be subtracted sufficiently, the output subsidy will

186 be more effective. Thus, it will encourage exports to enter the tariffed market with lower transaction costs. Combining a tariff scheme with some programs that aim to lower the transaction costs (for example, an output subsidy), can be a more effective approach in preventing market redirection leakage.

Badri and Khorana (2014) showed that tariff escalation on cotton and coffee had

191 developed mixed effects on export shares, depending on the initial economic structure. Tariff escalation may not reduce export shares due to its dependence on various other factors, including the structure and composition of international trade flows, as well as tariff

194 discrepancies across sectors and countries. However, it can be concluded that within a global 195 level, the dismissal of tariff escalation generates a higher average on export shares globally. 

create vast interlinkages among all sectors of the economy in Sudan. Lifting wheat's import tariff generates a negative impact on the economy. Further, the reduction of the wheat tariff has consequences on its imports, accompanied by a decrease in imports on other agricultural commodities and industrial and services sectors. An increase in wheat imports is found to decrease the domestic price and reduce the resources required in its production. The overall effect of a rise in wheat's import tariff is a reduction in wheat imports thus encourages the production for self-sufficiency of wheat in Sudan, along with a negative impact on GDP. Kim (2014) explored the effects of import-price shocks on labor, output, and total factor productivity (TFP) for a small open economy during the Korean crisis on 1997-1998. The simulated results showed that a significant increase in import price generated significant shrinkage in labor and output. A sizable drop in TFP was noticeable as well. This issue could be due to an anticipation measure from an increase in import price by utilising a substitution of imported goods with domestic intermediate goods. Moreover, this import substitution turned to result in negative effects on measured output (labor and productivity).

Javorcik and Narciso (2008) used product-level data on export activities from

212 Germany to ten Eastern European countries. It was to prove that the trade gap, which defined as a positive discrepancy between the exports values reported by Germany and the imports

214 values from Germany reported by an Eastern European importer, is positively correlated with 215 the tariff level in 8 out of 10 countries.

216 Based on the above studies, specific research on CPO tariff changes toward the price 217 and export activities is still limited. Hence, this research aims to explore whether tariff 218 imposed by India on Indonesia's CPO has a relationship with Indonesia's CPO price and 219 export activities. 
This study analysed whether the tariff has more significant impact on Indonesia's CPO export volume compared to the CPO price itself. Time series data were utilised to measure 222 the price and tariff elasticity to the Indonesia's CPO export volume. A modified 223 microeconomic approach (elasticity model) were used to analyse the significance of India's 224 tariff change is to the volume of exports. The related data used in this study was a monthly 225 data, started from 2015 until January 2020. The tariff data gathered from WTO was yearly data. Hence, the tariff data were interpolated into a monthly data. Since tariff is relatively static and has a proportional number (percentage, not changed frequently and generally imposed on commodity groups), the interpolation is not followed by any data loss.

230 the export volume.

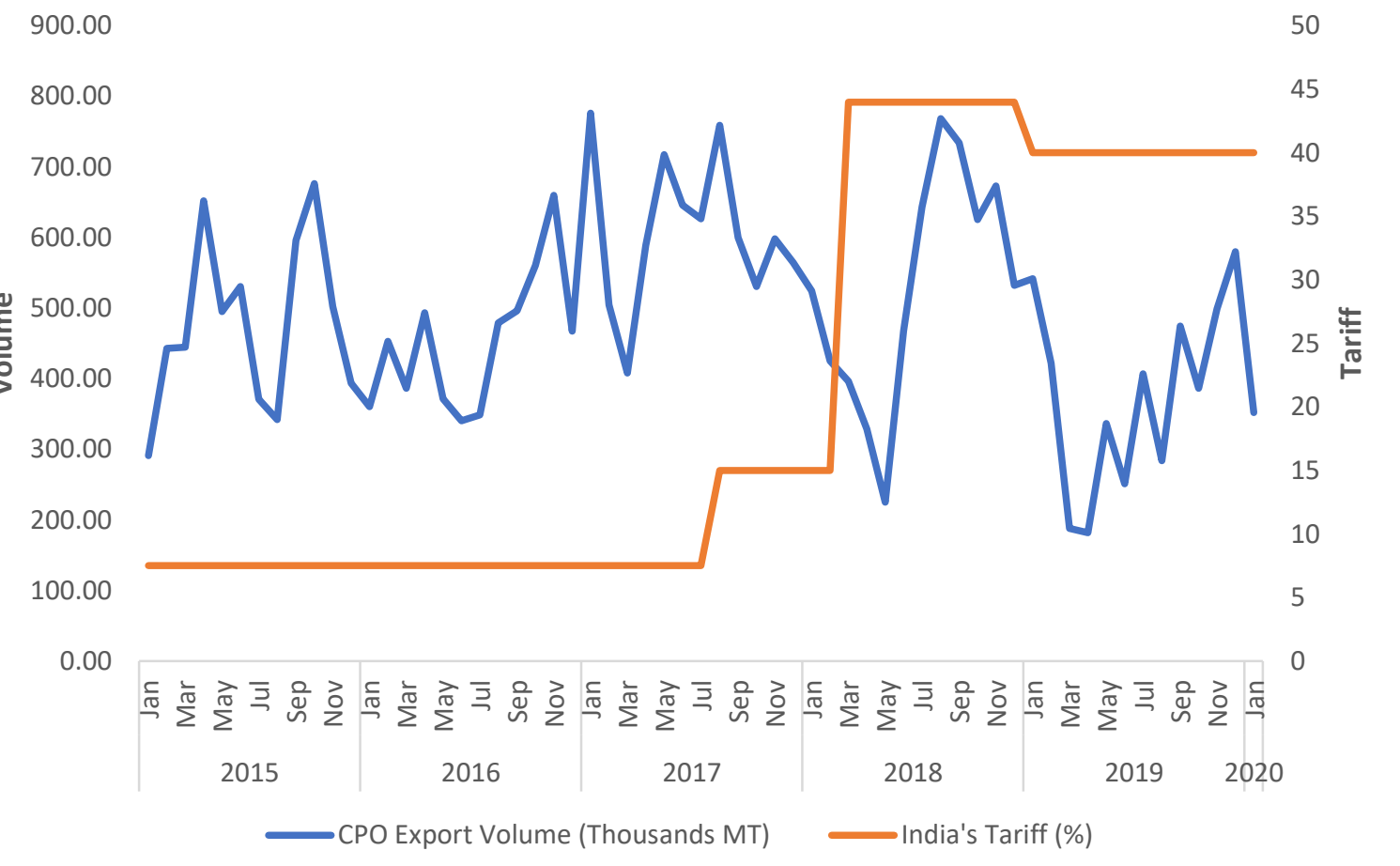


After the export volume and the tariff data were included within the same graph, it was shown that the tariff (orange line) does change frequently, as such the result is in stair-

237 like shape on the graph. The unchanged value within similar time range will result in 0 238 elasticity value. To address this issue, the timeline was then grouped into yearly timeframe in 239 order to catch any significant change in the variable. This method also converted the monthly 240 export volume into yearly value which the sum function was used.

In contrast, the price and the export volume data change more frequently therefore resulting in a more detailed timeframe. Monthly timeframe was used on price to export volume elasticity, where no specific treatment was needed in this case. The detailed graph of monthly CPO exports from 2015 to January 2020 and the CPO price is shown in Figure 4.

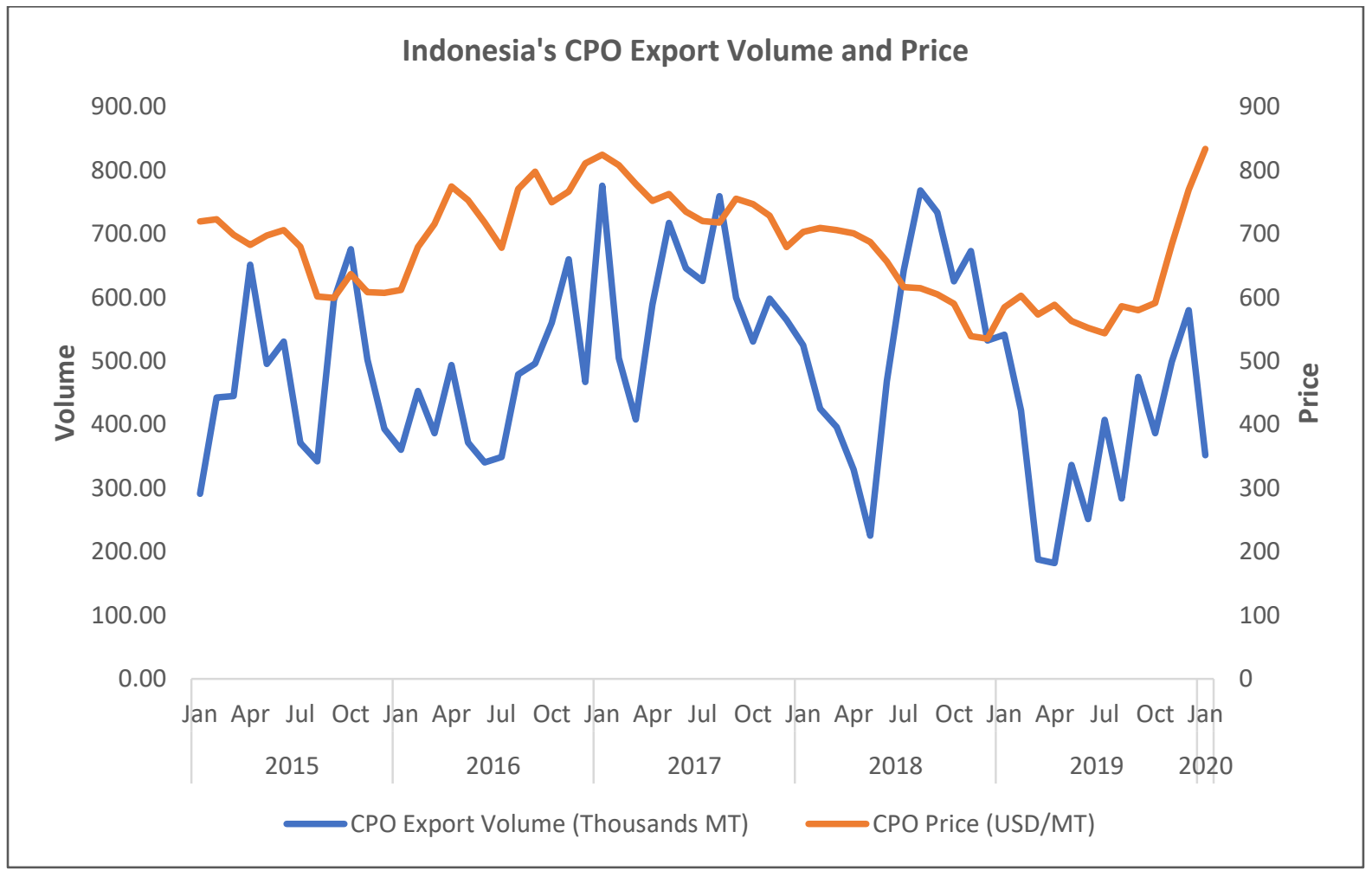

\section{Materials and Methods}


This study examines the iimpact of tariff changes held by India's trade authority on

Indonesia's CPO. To understand the magnitude of the tariff's impact to the number of CPO

251 exports, elasticity analysis approach was utilised to determine changes in CPO exports

following changes in the tariff. To deepen the analysis, this study also examined the CPO price elasticity relative to Indonesia's CPO export. To avoid biases, exports of CPO were measured through its volume. However, the value measurements (of elasticity) were included when the price change is insignificant. This study examined how the change in tariff might affect CPO exported by Indonesia to India and compare the dominant factor of the change in Indonesia's CPO; partner's tariff or CPO price itself.

\subsection{Indonesia to India's CPO Export Data}

The data used in this study are: (i) quantity of Indonesia's CPO export to India, (ii) the value of Indonesia's CPO export to India, (iii) world's CPO price, (iv) India's Tariff on Indonesia's CPO. The data stated on point (i) to (iii) are in monthly timeframe, ranging from January 2015 to January 2020. The data of India's tariff on CPO is stated in monthly timeframe (derived from yearly timeframe), since the tariff change did not occur frequently. Hence, the elasticity analysis carried out in this study is a point within the timeline. All changes on variables used in this study are stated on \%MtM (month to month) change. In this study, CPO is defined as vegetable oil commodities with HS code of 1511.

\subsection{Elasticity of India's Tariff on Indonesia's CPO Exports $(d Q / d T)$}

To examine the elasticity of India's tariff changes on CPO exports, this study used

271 elasticity analysis derived from demand elasticity on microeconomic analysis. The elasticity

272 model is stated as follows:

$$
\varepsilon_{T}=\frac{\Delta Q}{\Delta T} \times \frac{T_{1}}{Q_{1}}
$$


275 relative to tariff-to-quantity ratio.

$$
\varepsilon_{T}=\frac{\left(Q_{t}^{C P O}-Q_{t-1}^{C P O}\right)}{\left(T_{t}^{C P O}-T_{t-1}^{C P O}\right)} \times \frac{T_{t}^{C P O}}{Q_{t}^{C P O}}
$$

The change in quantity was measured by volume of CPO exported on $t$ period substracted by CPO exported on $t-1$ period. The change of tariff (in percentage) was measured as the gap between CPO tariff on $t$ and $t-1$ period. In other words, the elasticity of tariff on CPO exports can be stated as follows:

$$
\varepsilon_{T}=\frac{\% \Delta Q_{C P O}}{\% \Delta T_{C P O}}
$$

To simplify the calculations, the elasticity of tariff to the CPO was measured by the ratio of percentage changes on CPO's quantity to the percentage changes on India's tariff on CPO.

\subsection{Elasticity of CPO Price on Indonesia's CPO Exports $(d Q / d P)$}

To undertake in-depth analysis, the elasticity of CPO price changes on its export

volumes was examined in order to understand whether price factor has a dominant effect on Indonesia's CPO export raise. The elasticity model is stated as follows.

$$
\varepsilon_{T}=\frac{\Delta Q}{\Delta P} \times \frac{P_{1}}{Q_{1}}
$$

Elasticity of price is utilised to measure how CPO exports quantity (from Indonesia to India) is affected when the CPO price is changed by 1 . The elasticity itself is measured by

290 change on quantity with regards to its price, relative to price-to-quantity ratio.

$$
\varepsilon_{T}=\frac{\left(Q_{t}^{C P O}-Q_{t-1}^{C P O}\right)}{\left(P_{t}^{C P O}-P_{t-1}^{C P O}\right)} \times \frac{P_{t}^{C P O}}{Q_{t}^{C P O}}
$$


292 CPO exported on $t-1$ period. The change of price (in USD/MT) is measured by the gap 293 between CPO price on $t$ and $t-1$ period. In other words, the elasticity of tariff on CPO exports 294 can be stated as follows.

$$
\varepsilon_{T}=\frac{\% \Delta Q_{C P O}}{\% \Delta P_{C P O}}
$$

In this study, elasticity of price to the Indonesia's export CPO to India is measured by 296 the ratio of percentage changes on CPO's export quantity to the percentage changes on CPO's 297 world price.

\section{Result and Discussion}

Table 1. Calculation Results (BPS, WTO and Bloomberg)

\begin{tabular}{|c|c|c|c|c|c|c|c|c|}
\hline I & II & III & IV & $\mathbf{V}$ & VI & VII & VIII & IX \\
\hline Year & $\begin{array}{c}\text { Volume } \\
\text { (Thousands } \\
\text { MT) }\end{array}$ & $\begin{array}{c}\text { Tariff } \\
(\%)^{1}\end{array}$ & $\begin{array}{c}\text { Average } \\
\text { CPO Price } \\
(\text { USD/MT) })^{2}\end{array}$ & $\begin{array}{c}\text { Volume } \\
\text { Change } \\
(\%)\end{array}$ & $\begin{array}{c}\text { Average } \\
\text { Tariff } \\
\text { Change } \\
(\%)^{3}\end{array}$ & $\begin{array}{c}\text { Average } \\
\text { Price } \\
\text { Change } \\
(\%)^{4}\end{array}$ & & \\
\hline 2015 & 5,401 & 7.5 & 679.52 & 7.69 & -1.99 & -1.43 & -5.37 & -3.87 \\
\hline 2016 & 7,210 & 7.5 & 768.88 & 3.51 & 2.83 & 2.63 & 1.33 & 1.24 \\
\hline 2017 & 6,073 & 15 & 692.08 & 5.08 & 6.61 & -1.43 & -3.56 & 0.77 \\
\hline 2018 & 5,177 & 44 & 572.00 & 4.24 & 8.40 & -1.92 & -2.21 & 0.51 \\
\hline 2019 & 2,782 & 40 & 689.93 & 8.88 & 1.71 & 3.27 & 2.71 & 5.20 \\
\hline Average & 5,329 & 22.8 & 680.5 & 1.26 & 0.82 & 1.04 & -0.43 & 2.16 \\
\hline
\end{tabular}

Notes:

$303{ }^{1}$ Oficial tariff announced on WTO. 
$304{ }^{2}$ Yearly average world price of CPO commodity in year $t$.

$305{ }^{3}$ Calculated as the yearly average of average tariff imposed per metric tons on CPO (HS 306 1511)

$307{ }^{4}$ Yearly average world price change of CPO.

$308{ }^{5}$ Elasticity of CPO Price on Indonesia's CPO Export Volume to India (column VII / column 309 V)

$310{ }^{6}$ Elasticity of India's CPO Tariff on Indonesia's CPO Export Volume to India (column VI / 311 column V)

313 Based on calculation methods explained on previou section, positive and negative values on

314 elasticity only indicate negative or positive changes on CPO price or tariff. Refer to notes in 315 Appendix 1 for detailed calculations.

316 Table 1 shows the elasticity of CPO prices with an average export volume of -0.43 ,

317 while the elasticity between tariffs and CPO exports is 2.16. According to the results above,

318 tariff of CPO imports from Indonesia being imposed by Indian trade authority is relatively

319 elastic to the Indonesia's CPO export, since it has higher elasticity $(||>1)$ compared to the 320 price $(||<1)$ regardless the positive or negative signs. The positive signs indicates that 321 positive changes on determinant will be followed by positive change on the export volume 322 (and vice versa).

323 Negative value of average elasticity between the price and export volume indicates

324 that the price and quantity of India's demand on Indonesia's CPO has negative relationship (in 325 compliance with supply-demand law, wherein demand price has reversed impact on demand 326 quantity). The price elasticity, as stated above on the table, is also inelastic $(\|<1)$ meaning 327 that the raise in price by 1 USD/MT will followed by the decrease on quantities by less than 1 
thousand MT. On the other words, the price change of palm oil price will not reduce Indonesia's export quantity of CPO to India significantly.

Countries that have a comparative advantage in natural resources in their regions are specialised in economic activities in the production of export goods, while regions that cannot meet domestic demand for goods need to import (Murshed 2019). India cannot meet the needs of vegetable oil, therefore the country imports CPO from Indonesia which has comparative advantages. Import and export activities affect the trade relations between the two parties, where the relationship will affect the volume, prices and policies of each country. The production of goods for export has to attend several things, one of which is the quality of the goods. Quality playes a role in trade as a determinant of import decisions from other countries. Import decisions are also limited by price effects. Price elasticity of import demand comes from product differentiation. The strength of country-level market products is derived from the elasticity of import demand, and the elasticity of export supply (Lake and Linask 2016). Low elasticity occurs due to trade equations, therefore elasticity will be higher if the quality of production is more maintained (Shilva and Hidalgo 2020).

Export volumes are also affected by marginal production costs. Lower marginal production costs lead to lower exports. Higher export prices and quantities may occur, especially when exporters face a negative slope of the demand curve or marginal income (Dinopoulos, Kalyvitis, and Katsimi 2020). For developing countries, the most important factor that plays a role in determining imports is the price associated with the affordability of the country's economy (Shilva and Hidalgo 2020). Price elasticity plays a role in evaluating policy, used as a tool for understanding the impact of changes in tariffs for circulation and as a policy study.

The rise and fall in CPO prices are influenced by the quality and average world 352 prices. The average global CPO price always fluctuates, depending on the amount of CPO 
353 production from each country. Crude oil exports are the main factor affecting oil prices in 354 other countries (Bakirtas 2020). If the amount of CPO rises without an increase in demand, 355 there will be a surplus of world CPO and CPO prices will likely decline. Higher product 356 quality can increase demand (Dinopoulos et al. 2020) and should be accompanied by an 357 increase in the country's needs. Exports are affected by short-term fluctuations in relative 358 prices internationally (Raissi 2017). The level of imports in India is not affected by price changes. India considers the quality of CPO to make import decisions, on the condition that price changes are still in the country's ability to pay.

The tariff relationship to the export volume is elastic (in average), meaning that the percentage of change in volume exported to India will be higher than percentage of change in tariff imposed by India's trade authority. This finding is supported by the data visualisation between the tariff and export volume. The change in volume tends to be significantly changed with a lag of 2-3 months.

Trade restrictions can be carried out by setting import or export tariffs, it can also limit quotas. Tariff is an import duty charged on imported goods. Specific situations where tariffs do not apply to all countries are due to alternative trade agreements (Chae et al. 2019). Tariffs are pro-cycle driven by the behaviour of developing countries' tariff setting; tariffs are acyclical in developed countries. Pro-cycle follows the economic cycle (Lake and Linask 2016). Import and export tariffs are imposed through tax increase, as such the regulation is carried out by customs and has a more complex nature. Trade restrictions can dissolve buyersupplier relations (Chae et al. 2019). Determination of the imposed tariff will affect several aspects of trade. It explicitly affects prices, however for NTB case, general have an impact on import volumes (Soon 2020). Import tariffs are an obstacle for trading (Elsheikh et al. 2015). 
more likely to be consumed) (Robertson 1972). At the tactical level, tariffs are likely to boost

379 firms' sourcing costs and overall supply governance costs (including all costs related to

380 supplier identification, development, switching, and management). Meanwhile, at the

381 strategic level, tariffs could sway the firms' supply bases on its structure and complexity

382 (Chae et al. 2019).

383 However, a tariff change has its own costs. For example, when a country mitigates oil 384 supply disruption by implementing import tariffs, tariffs will raise the domestic oil price and generate negative effect on social welfare or consumer surplus. It can be concluded that the supposed optimal level of import tariff implemented by a country should balance the tradeoff. The trade-off is between the benefits of preventing economic losses due to oil supply disruption and the loss of decreasing social welfare as the effect of higher domestic oil prices (Zhang 2018).

The import tariff works similar to the emissions tax encountered by exporters.

391 Exporters with lower transaction costs are likely to reduce their tariffs by sustainable 392 production, while exporters with high transaction costs are likely to settle a full tariff. The 393 tariff must include the trade-off into account since its advantage at closing the 394 competitiveness channel may lose to its costs in creating the channel of market redirection. In 395 the case of palm oil, the trade-off between channels relies on: (i) the price sensitivity on 396 supply by unsustainable and unsustainable producers, and (ii) the price sensitivity on demand 397 for palm oil by the non-tariffed importer (Böhringer et al. 2018). 


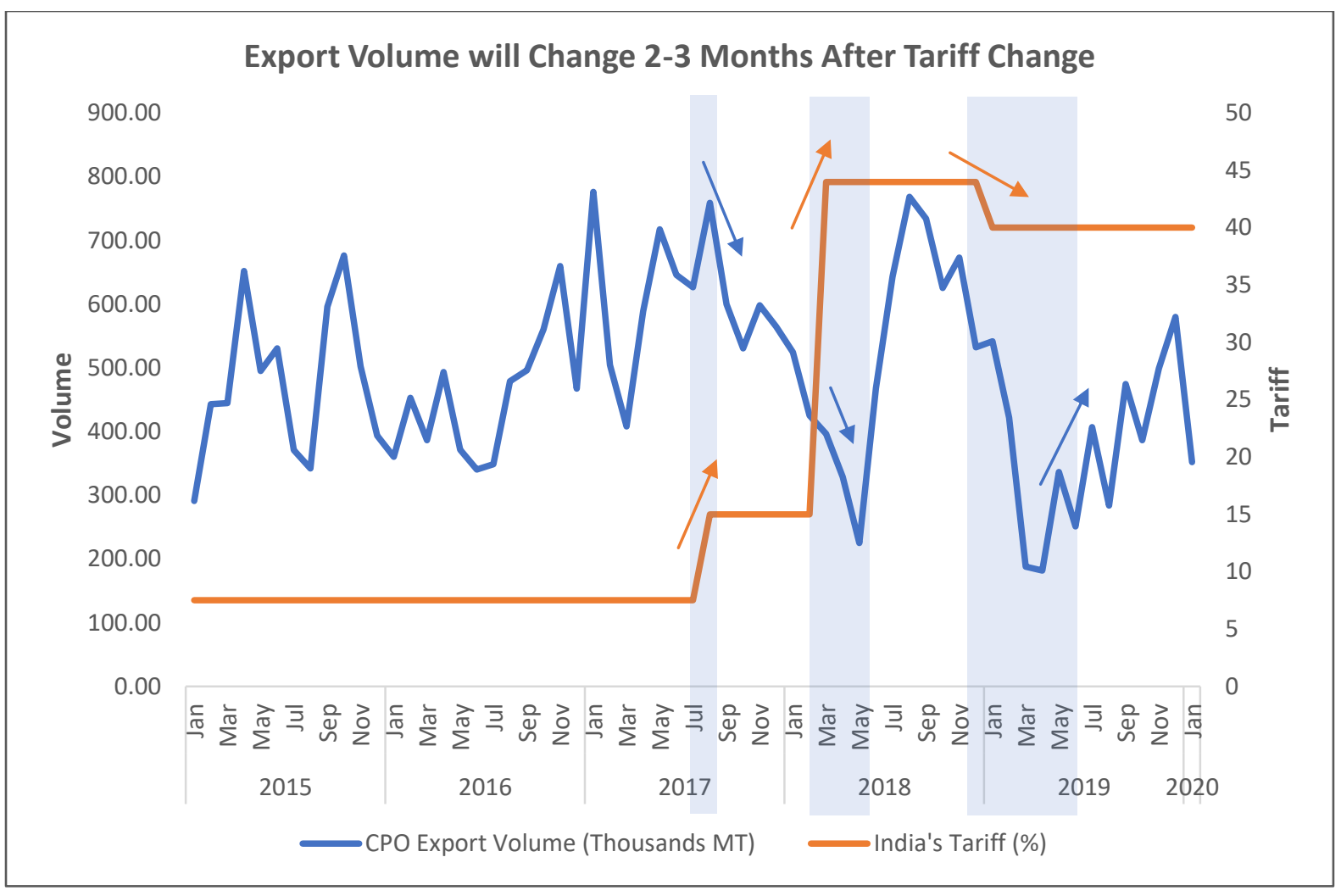

Figure 5. Lag of Export Volume Change Caused by Tariff Change (BPS, WHO)

In Figure 5, from 2015 to early 2020, India has experienced a change (increase/decrease) in import tariffs for 3 times. Tariff changes occurred in 2017 in July-

August and 2018 in February-March as well as the changes in December 2018-June 2019.

Every country does not necessarily be able to change import tariffs easily because there are regulations on governing import tariffs due to globalisation that supports international trade.

407 Tariff changes are marked by the severity, uncertainty of the interval period and geographical 408 coverage (Chae et al. 2019). The severity is related to what percentage change (increase / 409 decrease) is applied. The uncertainty of the tariff interval period is related to the tariff start 410 and end timing, the duration the tariff will be applied, and whether the tariff can be changed 411 through subsequent negotiations or permanent. The geographical coverage of a country will 412 affect the amount of tariffs from that country whether the import tarrif between one country 413 and another is the same or different. If tariff raise is only applied to one or several countries, 
414 then it is possible that importers will identify alternative exporters to possibly switch to other

415 exporters. Changes in tariffs will have an impact on increasing or decreasing imported goods,

416 affecting the prices of domestic goods, GDP revenues, changes in the trade balance,

417 investment and changes in private consumption (Elsheikh et al. 2015). Tariff changes do not

418 hold any correlation to industry characteristics such as stocks, concentration, employment,

419 wages, productivity and others (Bown and Tovar 2011).

420 The change in import tariffs imposed by India has several purposes. The main

421 objective is to protect the domestic production sector. Limiting imported goods can help to

422 staibilise the price of domestic goods because the amount of imported goods does not

423 experience excess hence public consumption will shift to domestic goods. In additionit

424 becomes one of the sources of state revenue derived from the tax sector, together with the

425 import tariff,. Changes in import tariffs will affect the amount of income earned by the

426 country. An increase in import tariffs will provide an increase in sources of state income and

427 vice versa. A decrease in import tariffs provide a decrease in sources of state revenue from 428 the tax sector.

India has experienced an energy deficit due power plants that were used required fuel 430 in the form of coal (Raissi 2017). Energy deficit due to coal depletion compelled the Indian 431 government to look for other type of fuels that are still available (alternative energy). To 432 maintain energy security in India, one alternative other than coal is to use CPO. India has its 433 own palm oil industry, however its production is still unable to meet the needs of the country.

434 Therefore, along with its own production, India also imports from Indonesia and Malaysia 435 hence the country's CPO needs are met. Energy security in India can be achieved by 436 increasing oil reserves and through import tariff instruments (Zhang et al. 2018). In order not 437 to depend too much on imported goods, India began to increase CPO production for the 438 domestic industry. Maximising production is carried out at the same time as providing 
439 protection and support to local industries. Energy supply is obtained through imports with 440 regard to prices that are still at a reasonable level.

441 in 2018 the Government of India increased the import tariffs, especially to Indonesia.

442 The imposed tariff rises was relatively high, with an increase of $30 \%$ (Figure 5). Increase in 443 import tariffs to Indonesia resulted in changes in the volume of Indonesia's CPO exports to 444 India. Indonesia's exports then declined sharply due to rising tariffs. Exports do not only 445 depend on external demand but also on the level of price competitiveness (Raissi and Tulin 2017). The decline in Indonesia's CPO exports to India was also influenced by differences in tariff prices imposed on Malaysia. Malaysia and Indonesia are located in one region, however 448 the geographical scope of India's imposed import tariffs is different between the two 449 countries (Chae et al. 2019). Malaysia and Indonesia are the biggest CPO importer countries 450 in the world, even in India. The higher import tariffs given to Indonesia impacts to higher 451 prices for $\mathrm{CPO}$ originating from Indonesia. The price of CPO originating from Indonesia cannot compete with the price of CPO originating from Malaysia due to higher price, causing a decrease in CPO demand. The setting of high tariffs has a potential to reduce the supply of imports, impacting the price of domestic products that have higher prices and therefore reduces social welfare (Zhang et al. 2018). An increase in import tariffs will affect the selling price of the goods in the country that imports the goods, hence a significant difference in prices with other products is anticipated and may cause the number of imported goods to decrease as people switch to consuming cheaper domestic goods. Increased import tariffs, which aimed at reducing imported goods, is for India to encourage CPO production in India 460 to become self-sufficient (Elsheikh et al. 2015). The increase will impact in the reduction of 461 the quantity of imported goods hance the amount of available goods fails meet the country's 462 needs for these goods. To cover the shortage of the required amount of goods, the country 463 encourages self-sufficiency, hence the needs of the goods can be met. The increase in tariffs 
464 is indeed to protect India, however this policy can affect global supply chains, and will affect import costs and production costs (Chae et al. 2019). However, based on our data analysis, the tariff policy imposed by India on Indonesia is elastic in volume, yet inelastic in price. Increase in import tariffs gives its own concern to importers (India), in which India is concerned of the availability of domestic commodities that are improportional to the needs, hence the country becomes lacking in CPO energy.

India's increased tariffs to Indonesia is actually aimed to reduce the volume of imports. However, based on the results of the analysis, the increase in tariffs does not affect the volume of CPO imports from Indonesia. The reason for the import volume in India is not affected by the increase in tariffs is because India is still dependent on CPO from Indonesia. India is experiencing energy shortages in the ability of coal and natural gas to constrain industry recovery (Raissi and Tulin 2017). The imposition of high import tariffs or policy restrictions on quota restrictions can cause energy insecurity to occur (Zhang 2014). cultivation (TL). Liberalisation is an agreement made by bilateral or multi-regional countries 479 for tariff reduction (Baldawin 2009). This policy is carried out to support free trade. The purpose of this policy is to utilise authority in cutting tariffs as such trade traffic becomes smoother. According to (Saggi et al. 2018), TL aims to eliminate trade restrictions between treaty member countries. TL policy also has an impact on the formation of human resources (Li et al. 2019), both in terms of cognitive, non-cognitive and social aspects. Trade liberalisation sets a maximum tariff to be applied to all members. TL provides special benefits for its members, however this policy can reduce non-member incentives (Saggi et al. 2018). Low rates are only available to members and not available to non-members. TL policies only improve environmental welfare if the related costs can be internalised (Murshed 
margins (Ketterer et al. 2015) and to preserve or prolong partner countries. The impact of trade liberalisation on other countries is fundamental microeconomic changes (poverty, productivity growth, labor demand, and product changes) (Bown and Tovar 2011).

Tariffs and Trade (GATT), in which import policy must not provide protection to domestic

494 producers without regard to other countries. For this reason, the country cannot determine tariffs or amend tariffs at its own will. The application of TL in terms of removing import and export tariffs is suitable for the application of trade, especially in the biofuel energy trade. The establishment of this TL is similar to increasing open trade. Tariff reduction due to TL can increase the use of renewable energy, one of which is CPO. Energy that contributes little to produce pollution, hence considered to be more environmentally friendly (Mahidin 2020).

500 The use of fossil energy is a threat to the world due to the destruction of nature, hence its availability is now running low and unable to meet future needs. Alternative energy that can

502 be used to replace the use of fossil energy is in the form of processed CPO which is 503 renewable and environmentally friendly energy. The existence of TL supports the openness 504 of trade, which will facilitate the transfer of renewable energy in developing countries 505 (Murshed 2019). This is one of the strategies to increase renewable energy consumption in developing countries. To optimise the flow of renewable energy, barriers of export and

507 import must be removed using the TL policy system. In the short term, the benefits of TL 508 policies cannot be felt, hence these policies must be carried out in the long term to feel the 509 benefits. According to Omri and Nguyen (2014), a 1\% increase in trade openness can 510 increase renewable energy consumption by $7.5 \%$, which translates to a decrease in $\mathrm{CO} 2$ 511 emissions by $0.2 \%$, where this gas is one of the contributors to GHG that causes an increase 512 in the earth's surface temperature (Uusitalo 2014). TL decisions can be used to promote the 513 trading of renewable energy sources which will later have an impact on increase in 
514 consumptionand market share, as well as the efficiency of their use (Murshed 2019). India

515 needs to align TL policies in the country's development strategy by considering more

516 renewable energy for national energy and playing an important role for Sustainable

517 Development Goals (SDGs). An increase in Indonesia's CPO exports means an increase in

518 the openness of international trade between Indonesia and India. Increased trade in renewable

519 energy does not mean limiting the greenhouse effect (Murshed 2019), because it needs public

520 understanding of the use of fossil fuels.

The elasticity between trade openness and renewable energy is less elastic (Murshed 2019). The effectiveness of TL policies in regards to the transition to renewable energy is also determined by the presence of unrenewable energy. Bioenergy availability and more affordable prices than fossil fuels can increase elasticity. Humans have been dependent on fossil resources for a long time as primary resources, hence time is required to replace them with renewable resources. There is a need for encouragement from countries that have used renewable energyin order for developing countries to gain a greater interest in using renewable energy rather than using fossil energy.

India began to recognise trade liberalism from 1991/1992, before that India used to 530 set limits on imported goods using large tariffs. India joined the WTO in 1997, therefore 531 import tariffs was adjusted to WTO tariffs (Bown and Tovar 2011). In 2009, the Regional 532 Comprehensive Economic Partnership (RCEP) was binding for the implementation of the 533 same tariff by India for CPO from Indonesia and Malaysia (Andri 2019). Import tariffs 534 imposed on Indonesia were reduced. Figure 5 shows tariff reduction provides an opportunity 535 for Indonesia to increase CPO exports again. Tariff reduction can increase imported goods, 536 which result in a reduction in the price of domestic goods because more goods are available 537 on the domestic market (Elsheikh et al. 2015). The reduction in import tariffs will affect the 538 selling price of the goods in the country that imports the goods Imported goods will have a 
539 lower price compared to the prices of domestic goods hence public consumption will be more

540 inclined to imported goods and will increase the number of imported goods. In addition to

541 reducing the import tariffs of India as an opportunity to increase exports for Indonesia, there

542 are also employment opportunities in the plantation sector or CPO industry in Indonesia

543 (Cheong 2016). Tariff reduction will increase the imports demand from developing countries

544 and increase exports for supplying countries. This increase in demand will result in an

545 increase in the amount of goods that have to be produced and can correlated with the needs of

546 the number of workers to provide jobs in the plantation or industrial sector. Tariff reduction

547 creates better free trade opportunities, however sacrifices the welfare of domestic farmers due

548 to low prices (Elsheikh et al. 2015; Defever et al. 2020). Tariff reduction will increase

549 demand for goods hence free trade is better, but on the other hand, the price of goods will be

550 lower and will have an impact on the income of farmers and workers that ultimately decrease

551 their welfare. TL policies in the form of reducing import tariffs can encourage exchanges to

552 promote the diffusion of renewable natural resources (Murshed 2019). Reducing import

553 tariffs will facilitate trade between countries, as such the possibility of imported goods

554 entering India will increase. Easier trade between countries will help countries that have used

555 renewable energy to encourage countries that still use fossil energy to switch to using more

556 profitable renewable energy. The reduced import tariffs were apparently replaced by new

557 policies. India has begun to use anti-dumping and safeguards policies to limit imports (Bown

558 and Tovar 2011).

559 The reduction in import tariffs by India does not only affect the export-import trade,

560 but affect the human resources in Indonesia. Similar to China, where China got a cut in

561 import tariffs from other WTO members after joining as WTO member. This tariff reduction

562 has an impact on the increase in Chinese exports. Oil palm cultivation and CPO industry are

563 labor-intensive industries, therefore an increase in exports will require more labor. Increasing 
needs of workers will provide more jobs for the community. The effect is the high dropout rate of young people who want to work ( $\mathrm{Li}$ et al. 2019). This is because labor-intensive industries only require workers with low levels of education and skills. The impact is caused by the low cognitive abilities, considering low levels of education will result in low income. Workers are also affected by non-cognitive effects, such as decreased satisfaction and mental weakness (prone to stress). Overall, human resources have low competitiveness and quality. The reduction in tariffs assigned to Indonesia should not be perceived from the benefits of expansion, but also needs to reviewed in terms of negative impacts to Indonesia. As mentioned by ( $\mathrm{Li}$ et al. 2019), there must be concern about how Indonesian human resources will be affected. For this reason, a strategy is formed by making policies in an effort to minimise impacts and improve Indonesia's human resources. The government can train young workers who have low skills or provide education to workers, as such there is an increase in the level of cognitive and skills and Indonesian human resources become more competitive globally.

According to Hayakawa et al. (2020) changes in a country's import tariffs do not only affect the amount of imported goods in the country but also affect the level of exports. This happens when shipping rates adjust to import tariffs and charged to both parties. Changes in import tariffs are faced with an increase in freight tariff adjustments (Hayakawa et al. 2020). Increased tariffs lead to rising domestic oil prices, which have a negative impact on consumer surpluses and social welfare (Zhang et al. 2018).

To determine the optimum import tariffs, the country must balance the trade off between the benefits obtained and the potential economic losses (Zhang et al. 2018). The balance between benefits and opportunity losses is intended to minimise undesired effects and optimise the success of the system or policy. Tariff determination motivates companies to review their supply bases (Chae et al. 2019). Changes in tariffs imposed by a country on 
another country will change the strategy of the exporter. The strategy is in the form of speed

590 of adaptation, which is determined by how quickly or slowly exporters make changes after

591 the imposition of tariff increases. The speed of this adaptation is important for exporters to

592 ensure economic activity continues to happen. This effort is a response given by exporters

593 facing a dynamic environment (Chae et al. 2019). Rapid response given by exporters will

594 produce changes in the complexity of goods, while the slow response of exporters can weaken trade relations between the two parties.

Import tariff policies can also be used to assist recovery for post-disaster countries, as

597 carried out by the European Union (EU) to Pakistan (Cheong 2016). The flood disaster

598 paralysed the economy in Pakistan. After the disaster, the Pakistani government restored the

599 economy through trade. To support economic recovery in Pakistan, the EU cut import tariffs

600 from Pakistan. The low EU import tariffs for Pakistan was to support exports increase and to

601 help Pakistan re-develop the country's economy. Trade concessions and policies for

602 economic recovery are considered successful in restoring the economy in Pakistan. Lowering

603 import tariffs is the same as reducing economic uncertainty. After the disaster, a lot of aid

604 flowed to restore the economy. Since post-disaster official assistance has weaknesses, the

605 policy of reducing import tariffs in other countries can help improve the economy. Tariff

606 reductions imposed in order to improve the economy of other countries after a disaster can be

607 used to refinance infrastructure, provide disaster relief, and minimise political instability

608 caused by disasters

609 Market changes, such as the tariff imposition, encourage firms to adjust their 610 approaches to managing suppliers, therefore affecting the overall complexity of their supply

611 bases. The adaptation phenomenon were widely discussed in the early systems theory

612 literature (Von Bertalanffy 1968). Thus, tariff is an important factor that has the ability to 613 influence the decisions of supply management. Due to the uncertainty of changes in tariffs, 
614 exporters may experience difficulties in planning their supply base for the long term, given

615 that the majority of tariffs are potentially subject to renegotiation (Chae et al. 2019). The US

616 car manufacturer, Ford, for example, ignored its plans to build a new factory in Mexico and

617 decided to build its Focus compact car in an existing US facility after the US President called

618 for a 35\% tariff for cars manufactured abroad (Welch and Merrill 2017).

619 CPO import volume can also be influenced by substitute goods. The complementary

620 effect and substitution in consumption, as well as the price of substitute goods can affect oil

621 palm (Santeramo and Searle 2019). Palm oil fuel is used for many needs, including for food

622 and transportation. The use of palm oil fuel can be replaced with soybean oil. If the price of

623 soybean oil is lower and has more supplies as well as better quality, it is likely for the

624 consumers to shift to palm oil.

625 Trade (export-import) is an indicator of economic growth. Economic growth can experience a surplus or deficit, which is usually associated with export and import values.

627 The value of exports and imports can change depending on changes in tariffs of a country.

628 Imposing an increase and decrease in tariffs will have both positive and negative impacts on

629 both parties. As previously discussed, the impact of increased tariffs on exporting countries is

630 a decrease in export volumes and economic growth. For the importing country, it can

631 suppress imported goods in the country, hence stabilise the price of domestic goods and

632 protect domestic producers. The country can maximise production by self-sufficiency,

633 however the country will lack products to meet its needs if this strategy fails. When tariffs are

634 reduced, exporters will have an impact on increasing volume. Many jobs will be created, but

635 it will reduce the quality of human resources in the exporting country. In the importing

636 country, fulfillment of needs will occur, with the possibility of turning off domestic

637 production. The government must carefully consider which policies will be implemented to

638 deal with the occurring changes. 
640 tariffs in the short term. There is a difference in the effect of import tariffs from the long term

641 and in the short term in terms of the development of the trade balance. The short term has no

642 significant effect on the development of the trade balance which is a positive sign, hence it is

643 likely to have an impact on the long term development (Murshed, 2019)

644

\section{Conclusion}

646 According to the results above, tariff of CPO imports from Indonesia imposed by Indian trade

647 authority is relatively elastic to the Indonesia's CPO export since it has higher elasticity ( $\left|\varepsilon_{T}\right|$

$648>1)$ compared to the price $\left(\left|\varepsilon_{P}\right|<1\right)$ regardless of the positive or negative signs. Price 649 elasticity, as stated above, is inelastic $\left(\left|\varepsilon_{P}\right|<1\right)$, meaning that the raise in price by 1

650 USD/MT will be followed by the decrease on quantities by less than 1 thousand MT. India's 651 tariff on CPO relationship to the Indonesia's CPO export volume is elastic in average, 652 meaning that the percentage of change in volume exported to India will be higher compared 653 to percentage of change in tariff imposed by India's trade authority. Tariff elasticity shows 654 elastic elasticity ( $\left|\varepsilon_{T}\right|>1$ ), meaning that the change in imposed tariff by $1 \%$ increase per MT 655 will be followed by the decrease on quantities by more than 1 thousand MT, with a lag of 2-3 656 months. Negative value of average elasticity between the price and export volume indicates 657 that the price and quantity of India's demand on Indonesia's CPO has a negative relationship, 658 which complies with supply-demand law, where demand price has a reversed impact on 659 demand quantity.

660

\section{References}


662 Andri Y (2019) Indonesia Manfaatkan RCEP untuk Muluskan Ekspor CPO ke India. https://ekonomi.bisnis.com/read/20191025/12/1163263/indonesia-manfaatkan-rcepuntuk-muluskan-ekspor-cpo-ke-india. Accessed 14 July 2020.

Badri NG, Khorana S (2014) Tariff escalation, export shares and economy-wide welfare: A computable general equilibrium approach. Economic Modelling 41:109-118.

Baldawin RE (2009) Trade negotiations within the GATT/WTO framework: A survey of 668 successes and failures. Journal of Policy Modeling 31(4):515-525.

Bank Indonesia (2020). Bank Indonesia Economic and Finance Statistics: Non-oil and gas export volumes. https://www.bi.go.id/seki/tabel/TABEL5_14.xls

Barkitas T, Akpolat AG (2020) The relationship between crude oil exports, crude oil prices and military expenditures in some OPEC countries. Resources Policy 67:101659.

Böhringer C, Carbone JC, Rutherford TF (2018) Embodied carbon tariffs. Scand. J. Econ. 120:183-210.

Bown CP, Tovar P (2011) Trade liberalization, antidumping, and safeguards: Evidence from India's tariff reform. Journal of Development Economics 96 (1):115-125.

Chae S, Mena C, Polyviou M, Rogers ZS, Wiedmer R (2019) The effects of tariff increases on supply base complexity: A conceptual framework. Journal of Purchasing and Supply Management 25(4):100556.

680 Cheong J, Kwak DW, Tang KK ( 2017) Trade to aid: EU's temporary tariff waivers for flood681 hit Pakistan. Journal of Development Economics 125:70-88.

682 Corley R (2009) How much palm oil do we need? Environmental Science Policy 12:134-139.

683 Defever F, Imbruno M, Kneller R (2020) Trade liberalization, input intermediaries and firm 684 productivity: Evidence from China. Journal of International Economics 126:103329. 
685 Dinopoulos E, Kalyvitis S, Katsimi M (2020) Variable export price elasticity, product 686 quality, and credit constraints: Theory and evidence from Greek firms. Journal of International Money and Finance 104:102135.

Elsheikh OE, Elbushra AA, Salih AAA (2015) Economic impacts of changes in wheat's import tariff on the Sudanese economy. Journal of the Saudi Society of Agricultural Sciences 14(1):68-75.

691 Faostat (2020) Food and Agriculture Organization statistical database. 692 http://faostat3.fao.org/browse/Q/QC/E. Accessed June 2020.

693

Greenaway D (1983) International trade policy: From tariffs to the new protectionism. Macmillan International Higher Education.

695

Hashim K, Tahiruddin S, Asis AJ (2012) Palm and Palm Kernel Oil Production and 696 Processing in Malaysia and Indonesia. Palm Oil 235-250.

697 Hayakawa K, Ishikawa J, Tarui N (2020) What goes around comes around: Export-enhancing 698 effects of import-tariff reductions. Journal of International Economics 126: 103362.

699 Himics M, Listorti G, Tonini A (2020) Simulated economic impacts in applied trade 700 modelling: A comparison of tariff aggregation approaches. Economic Modelling 701 $87: 344-357$.

702

Imbruno M (2016) China and WTO liberalization: Imports, tariffs and non-tariff barriers. 703 China Economic Review 38:222-237.

704 InfoSawit (2020). https://www.infosawit.com/pages/plantations-company/. Accessed 20 705 April 2020.

Javorcik BS, Narciso G (2008) Differentiated products and evasion of import tariffs. Journal 707 of International Economics 76(2):208-222. 
Ketterer TD, Bernhofen DM, Milner C (2015) The impact of trade preferences on multilateral tariff cuts: Evidence for Japan. Journal of the Japanese and International Economies 38:31-51.

Kim ST (2014) The price of imports and TFP: Application to the Korean crisis of 19971998. Review of Economic Dynamics 17(1):39-51.

Lake J, Linask MK (2016) Could tariffs be pro-cyclical? Journal of International Economics 103:124-146.

Li J, Lu Y, Song H, Xie H (2019) Long-term impact of trade liberalization on human capital formation. Journal of Comparative Economics 47(4):946-961.

Mahidin S, Erdiwansyah H, Hisbullah, Hayati AP, Zhafran M, Sidiq MA, Rinaldi A, Fitria B, Tarisma R, Bindar Y (2020) Analysis of power from palm oil solid waste for biomass power plants: A case study in Aceh Province. Chemosphere 253:126714.

MoA [Ministry of Agriculture] (2013) Tekad penerapan visi 35: 26 dicanangkan pada konferensi semarak seratus tahun kelapa sawit Indonesia. Ministry of Agriculture, Jakarta.

MoA (2016) Outlook Kelapa Sawit. In: Agricultural Data Center and Information System.

Mukherjee I, Sovacool BK (2014) Palm oil-based biofuels and sustainability in south-east Asia: a review of Indonesia, Malaysia, and Thailand. Renewable Sust Energ Rev

Murshed M (2020) Are Trade Liberalization policies aligned with Renewable Energy Transition in low and middle income countries? An Instrumental Variable approach. Renewable Energy 151:1110-1123

731 Omri A, Nguyen DK (2014) On the determinants of renewable energy consumption: International evidence. Energy 72:554-560. 
733 Purnomo H, Okarda B, Dermawan A, Ilham QP, Pacheco P, Nurfatriani F, Suhendang E (2020) Reconciling oil palm economic development and environmental conservation in Indonesia: A value chain dynamic approach. Forest Policy and Economics 111:102089.

Raissi M, Tulin V (2018) Price and income elasticity of Indian exports-The role of supplyside bottlenecks. The Quarterly Review of Economics and Finance 68:39-45 .

Robertson D. (1972). International trade policy. Macmillan International Higher Education.

Saggi K, Wong WF, Yildiz HM (2019) Should the WTO require free trade agreements to eliminate internal tariffs? Journal of International Economics 118:316-330.

Santeramo FG, Searle S (2019) Linking soy oil demand from the US Renewable Fuel Standard to palm oil expansion through an analysis on vegetable oil price elasticities.

Santika T, Wilson KA, Budiharta S, Law EA, Poh TM, Ancrenaz M, ... Meijaard E (2019) Does oil palm agriculture help alleviate poverty? A multidimensional counterfactual assessment of oil palm development in Indonesia. World Development 120:105-117.

Silva ADBD, Hidalgo AB (2020) Price elasticity in import demand equations considering product quality: Estimates for the Brazilian economy (1996-2013). EconomiA.

Soon BM, Thompson W (2020) Non-tariff barrier on chicken imports into Russia: Impact on production, trade and prices. Journal of Policy Modeling 42(3):583-596.

Tim Riset PASPI 2018. Perubahan komposisi ekspor sawit dan perannya dalam neraca perdagangan Indonesia. In: Analisis Isu Strategis Sawit IV(19/05/2018).

United States Department of Agriculture F.A. Service (2017) Oilseeds: World Markets and Trade. United States Department of Agriculture, Washington, DC, USA. 
Uusitalo V, Vaisanen S, Havukainen J, Havukainen M, Soukka R, Louranen M (2014) Carbon footprint of renewable diesel from palm oil, jatropha oil and rapeseed oil. Renewable Energy 69:103-113.

Von Bertalanffy L (1968) General System Theory: Foundations, Development, Application. George Braziller, New York, NY.

Welch D, Merrill D (2017) Why Trump Tariffs on Mexican Cars Probably Won't Stop Job Flight. Bloomberg. https://www.bloomberg.com/graphics/2017-trumpmexico-autojobs/. Accessed 14 July 2020.

WTO (2020) WTO: International Trade Tariff Data. https://www.wto.org/english/res_e/statis_e/statis_e.htm

Wilman EA (2019) Market redirection leakage in the palm oil market. Ecological Economics 159:226-234.

Zhang X (2014) Optimal strategic oil stockpiling and import tariffs: The case of China. Energy Economics 45:463-474.

Zhang X, Zheng X, Qin P, Xie L (2018) Oil import tariff game for energy security: The case of China and India. Energy Economics 72:255-262.

\section{Appendices and Notes}

Appendix 1: Data Used in this Research

\begin{tabular}{|c|c|c|c|c|c|c|c|c|c|c|c|c|}
\hline $\mathbf{i}$ & ii & iiii & iv & $\mathbf{v}$ & vi & vii & $\begin{array}{l}\text { viii } \\
\end{array}$ & $\mathbf{i x}$ & $\mathbf{x}$ & $\begin{array}{l}\mathbf{x i} \\
\end{array}$ & xii & $\begin{array}{l}\text { xiii } \\
\end{array}$ \\
\hline Year & Month & $\begin{array}{l}\text { Total CPO } \\
\text { Export } \\
\text { Volume } \\
\text { (Thousands } \\
\text { MT) }\end{array}$ & $\begin{array}{l}\text { Total } \\
\text { CPO } \\
\text { Export } \\
\text { Value } \\
\text { (Millions } \\
\text { USD) }\end{array}$ & $\begin{array}{l}\text { Price + } \\
\text { Tariff Avg } \\
\text { (USD/MT) }\end{array}$ & $\begin{array}{l}\text { Price w/o } \\
\text { tariff } \\
\text { (USD/MT) }\end{array}$ & $\begin{array}{l}\text { Tarif } \\
(\%)\end{array}$ & $\begin{array}{l}\text { Tariff/MT } \\
\text { (USD/MT) }\end{array}$ & $\begin{array}{l}\text { Q } \\
\text { Changes } \\
(\%)\end{array}$ & $\begin{array}{l}P \\
\text { change } \\
(\%)\end{array}$ & $\begin{array}{l}\text { Tariff } \\
\text { Change } \\
\text { (\% per } \\
\text { MT) }\end{array}$ & $\mathrm{dQ} / \mathrm{dP}$ & $d Q / d T$ \\
\hline 2015 & Jan & 291.25 & 183.74 & 630.86 & 586.85 & 7.5 & 44.01 & - & - & - & - & - \\
\hline & Feb & 442.93 & 273.68 & 617.87 & 574.76 & 7.5 & 43.11 & 52.08 & 0.47 & -2.06 & 110.2 & -25.3 \\
\hline
\end{tabular}




\begin{tabular}{|c|c|c|c|c|c|c|c|c|c|c|c|c|}
\hline & Mar & 444.91 & 273.71 & 615.21 & 572.29 & 7.5 & 42.92 & 0.45 & -3.34 & -0.43 & -0.1 & -1.0 \\
\hline & Apr & 651.85 & 390.96 & 599.76 & 557.92 & 7.5 & 41.84 & 46.51 & -2.31 & -2.51 & -20.2 & -18.5 \\
\hline & May & 495.38 & 294.88 & 595.26 & 553.73 & 7.5 & 41.53 & -24.00 & 2.14 & -0.75 & -11.2 & 32.0 \\
\hline & Jun & 530.57 & 318.74 & 600.74 & 558.83 & 7.5 & 41.91 & 7.10 & 1.23 & 0.92 & 5.8 & 7.7 \\
\hline & Jul & 371.16 & 220.98 & 595.39 & 553.85 & 7.5 & 41.54 & -30.04 & -3.67 & -0.89 & 8.2 & 33.7 \\
\hline & Aug & 341.97 & 187.58 & 548.54 & 510.27 & 7.5 & 38.27 & -7.86 & -11.56 & -7.87 & 0.7 & 1.0 \\
\hline & Sep & 595.75 & 284.76 & 477.98 & 444.63 & 7.5 & 33.35 & 74.21 & -0.31 & -12.86 & -237.4 & -5.8 \\
\hline & Oct & 676.31 & 339.04 & 501.31 & 466.33 & 7.5 & 34.97 & 13.52 & 6.20 & 4.88 & 2.2 & 2.8 \\
\hline & Nov & 502.19 & 252.27 & 502.34 & 467.30 & 7.5 & 35.05 & -25.75 & -4.47 & 0.21 & 5.8 & -124.7 \\
\hline & Dec & 393.47 & 196.71 & 499.92 & 465.04 & 7.5 & 34.88 & -21.65 & -0.14 & -0.48 & 158.6 & 44.9 \\
\hline \multirow[t]{12}{*}{2016} & Jan & 360.16 & 186.50 & 517.82 & 481.69 & 7.5 & 36.13 & -8.47 & 0.70 & 3.58 & -12.1 & -2.4 \\
\hline & Feb & 452.93 & 243.07 & 536.66 & 499.22 & 7.5 & 37.44 & 25.76 & 11.04 & 3.64 & 2.3 & 7.1 \\
\hline & Mar & 386.69 & 225.43 & 582.98 & 542.30 & 7.5 & 40.67 & -14.63 & 5.42 & 8.63 & -2.7 & -1.7 \\
\hline & Apr & 493.72 & 314.94 & 637.89 & 593.39 & 7.5 & 44.50 & 27.68 & 8.25 & 9.42 & 3.4 & 2.9 \\
\hline & May & 371.54 & 244.85 & 659.03 & 613.05 & 7.5 & 45.98 & -24.75 & -2.78 & 3.31 & 8.9 & -7.5 \\
\hline & Jun & 340.32 & 221.69 & 651.42 & 605.97 & 7.5 & 45.45 & -8.40 & -4.68 & -1.15 & 1.8 & 7.3 \\
\hline & Jul & 348.96 & 217.79 & 624.12 & 580.58 & 7.5 & 43.54 & 2.54 & -5.57 & -4.19 & -0.5 & -0.6 \\
\hline & Aug & 478.78 & 300.95 & 628.58 & 584.72 & 7.5 & 43.85 & 37.20 & 13.69 & 0.71 & 2.7 & 52.1 \\
\hline & Sep & 496.25 & 340.45 & 686.04 & 638.17 & 7.5 & 47.86 & 3.65 & 3.48 & 9.14 & 1.0 & 0.4 \\
\hline & Oct & 560.45 & 380.50 & 678.92 & 631.55 & 7.5 & 47.37 & 12.94 & -6.03 & -1.04 & -2.1 & -12.5 \\
\hline & Nov & 659.96 & 440.55 & 667.55 & 620.97 & 7.5 & 46.57 & 17.76 & 2.29 & -1.67 & 7.7 & -10.6 \\
\hline & Dec & 467.24 & 323.22 & 691.76 & 643.50 & 7.5 & 48.26 & -29.20 & 5.80 & 3.63 & -5.0 & -8.1 \\
\hline \multirow[t]{12}{*}{2017} & Jan & 776.07 & 562.34 & 724.60 & 674.04 & 7.5 & 50.55 & 66.10 & 1.68 & 4.75 & 39.4 & 13.9 \\
\hline & Feb & 504.35 & 376.03 & 745.58 & 693.57 & 7.5 & 52.02 & -35.01 & -1.99 & 2.90 & 17.6 & -12.1 \\
\hline & Mar & 407.84 & 289.21 & 709.14 & 659.67 & 7.5 & 49.47 & -19.14 & -3.70 & -4.89 & 5.2 & 3.9 \\
\hline & Apr & 588.83 & 398.08 & 676.05 & 628.88 & 7.5 & 47.17 & 44.38 & -3.42 & -4.67 & -13.0 & -9.5 \\
\hline & May & 717.68 & 473.65 & 659.97 & 613.92 & 7.5 & 46.04 & 21.88 & 1.42 & -2.38 & 15.4 & -9.2 \\
\hline & Jun & 645.93 & 422.29 & 653.77 & 608.16 & 7.5 & 45.61 & -10.00 & -3.62 & -0.94 & 2.8 & 10.6 \\
\hline & Jul & 626.29 & 397.05 & 633.98 & 589.75 & 7.5 & 44.23 & -3.04 & -1.99 & -3.03 & 1.5 & 1.0 \\
\hline & Aug & 759.29 & 474.80 & 625.32 & 543.76 & 15 & 81.56 & 21.24 & -0.35 & 84.40 & -60.5 & 0.3 \\
\hline & Sep & 600.04 & 390.30 & 650.46 & 565.62 & 15 & 84.84 & -20.97 & 5.20 & 4.02 & -4.0 & -5.2 \\
\hline & Oct & 530.85 & 350.08 & 659.48 & 573.46 & 15 & 86.02 & -11.53 & -1.12 & 1.39 & 10.3 & -8.3 \\
\hline & Nov & 598.11 & 397.27 & 664.21 & 577.57 & 15 & 86.64 & 12.67 & -2.40 & 0.72 & -5.3 & 17.7 \\
\hline & Dec & 564.62 & 364.07 & 644.81 & 560.71 & 15 & 84.11 & -5.60 & -6.82 & -2.92 & 0.8 & 1.9 \\
\hline \multirow[t]{5}{*}{2018} & Jan & 524.75 & 328.78 & 626.55 & 544.83 & 15 & 81.72 & -7.06 & 3.57 & -2.83 & -2.0 & 2.5 \\
\hline & Feb & 424.98 & 270.19 & 635.78 & 552.85 & 15 & 82.93 & -19.01 & 0.85 & 1.47 & -22.3 & -12.9 \\
\hline & Mar & 396.25 & 254.42 & 642.07 & 445.88 & 44 & 196.19 & -6.76 & -0.46 & 136.58 & 14.8 & 0.0 \\
\hline & Apr & 328.88 & 211.47 & 643.02 & 446.54 & 44 & 196.48 & -17.00 & -0.71 & 0.15 & 24.0 & -114.6 \\
\hline & May & 224.96 & 139.55 & 620.35 & 430.80 & 44 & 189.55 & -31.60 & -2.00 & -3.53 & 15.8 & 9.0 \\
\hline
\end{tabular}




\begin{tabular}{|c|c|c|c|c|c|c|c|c|c|c|c|c|}
\hline & Jun & 468.08 & 286.49 & 612.07 & 425.05 & 44 & 187.02 & 108.07 & -4.46 & -1.34 & -24.2 & -80.9 \\
\hline & Jul & 643.25 & 368.39 & 572.70 & 397.71 & 44 & 174.99 & 37.42 & -6.15 & -6.43 & -6.1 & -5.8 \\
\hline & Aug & 768.43 & 421.29 & 548.25 & 380.73 & 44 & 167.52 & 19.46 & -0.23 & -4.27 & -86.3 & -4.6 \\
\hline & Sep & 733.90 & 395.16 & 538.44 & 373.92 & 44 & 164.52 & -4.49 & -1.56 & -1.79 & 2.9 & 2.5 \\
\hline & Oct & 625.57 & 319.68 & 511.02 & 354.87 & 44 & 156.14 & -14.76 & -2.45 & -5.09 & 6.0 & 2.9 \\
\hline & Nov & 672.94 & 324.46 & 482.16 & 334.83 & 44 & 147.33 & 7.57 & -8.68 & -5.65 & -0.9 & -1.3 \\
\hline & Dec & 532.11 & 239.92 & 450.89 & 313.12 & 44 & 137.77 & -20.93 & -0.76 & -6.49 & 27.7 & 3.2 \\
\hline 2019 & Jan & 541.53 & 242.97 & 448.67 & 320.48 & 40 & 128.19 & 1.77 & 9.26 & -6.95 & 0.2 & -0.3 \\
\hline & Feb & 422.11 & 204.02 & 483.34 & 345.24 & 40 & 138.10 & -22.05 & 3.15 & 7.73 & -7.0 & -2.9 \\
\hline & Mar & 187.72 & 91.99 & 490.02 & 350.01 & 40 & 140.01 & -55.53 & -4.97 & 1.38 & 11.2 & -40.2 \\
\hline & Apr & 181.92 & 88.62 & 487.13 & 347.95 & 40 & 139.18 & -3.09 & 2.69 & -0.59 & -1.1 & 5.2 \\
\hline & May & 336.62 & 159.75 & 474.58 & 338.98 & 40 & 135.59 & 85.04 & -4.29 & -2.58 & $\begin{array}{l}-19.8 \\
\end{array}$ & -33.0 \\
\hline & Jun & 251.41 & 115.12 & 457.90 & 327.07 & 40 & 130.83 & -25.31 & -1.95 & -3.51 & 12.9 & 7.2 \\
\hline & Jul & 407.20 & 183.71 & 451.15 & 322.25 & 40 & 128.90 & 61.96 & -1.50 & -1.47 & -41.2 & -42.0 \\
\hline & Aug & 283.58 & 129.69 & 457.32 & 326.66 & 40 & 130.66 & -30.36 & 7.77 & 1.37 & -3.9 & -22.2 \\
\hline & Sep & 474.80 & 234.86 & 494.65 & 353.32 & 40 & 141.33 & 67.43 & -0.99 & 8.16 & -67.9 & 8.3 \\
\hline & Oct & 386.60 & 189.17 & 489.32 & 349.52 & 40 & 139.81 & -18.58 & 1.90 & -1.08 & -9.8 & 17.3 \\
\hline & Nov & 498.90 & 261.84 & 524.82 & 374.87 & 40 & 149.95 & 29.05 & 15.56 & 7.26 & 1.9 & 4.0 \\
\hline & Dec & 580.08 & 337.30 & 581.47 & 415.34 & 40 & 166.13 & 16.27 & 12.66 & 10.79 & 1.3 & 1.5 \\
\hline 2020 & Jan & 351.99 & 250.99 & 713.07 & 509.33 & 40 & 203.73 & -39.32 & 8.32 & 22.63 & -4.7 & -1.7 \\
\hline
\end{tabular}

775

776

Calculation Notes

- Column v: Since volume and values included here are various CPO commodities

(with prefix of HS 1511), we count average price by dividing total export value (column iv) with export volume (column iii) and times it with 1000 (thousand MT and millions USD to USD/MT conversion).

- Column vi: To earn average prices per metric tons without tariff, we calculated this variable through the price (column V) times with 100/(100+ tariff percentage on column vii).

- Column viii $=$ column $\mathrm{v}-$ column vi

- Column xi: changes on average tariff per MT (column viii) 
Figures

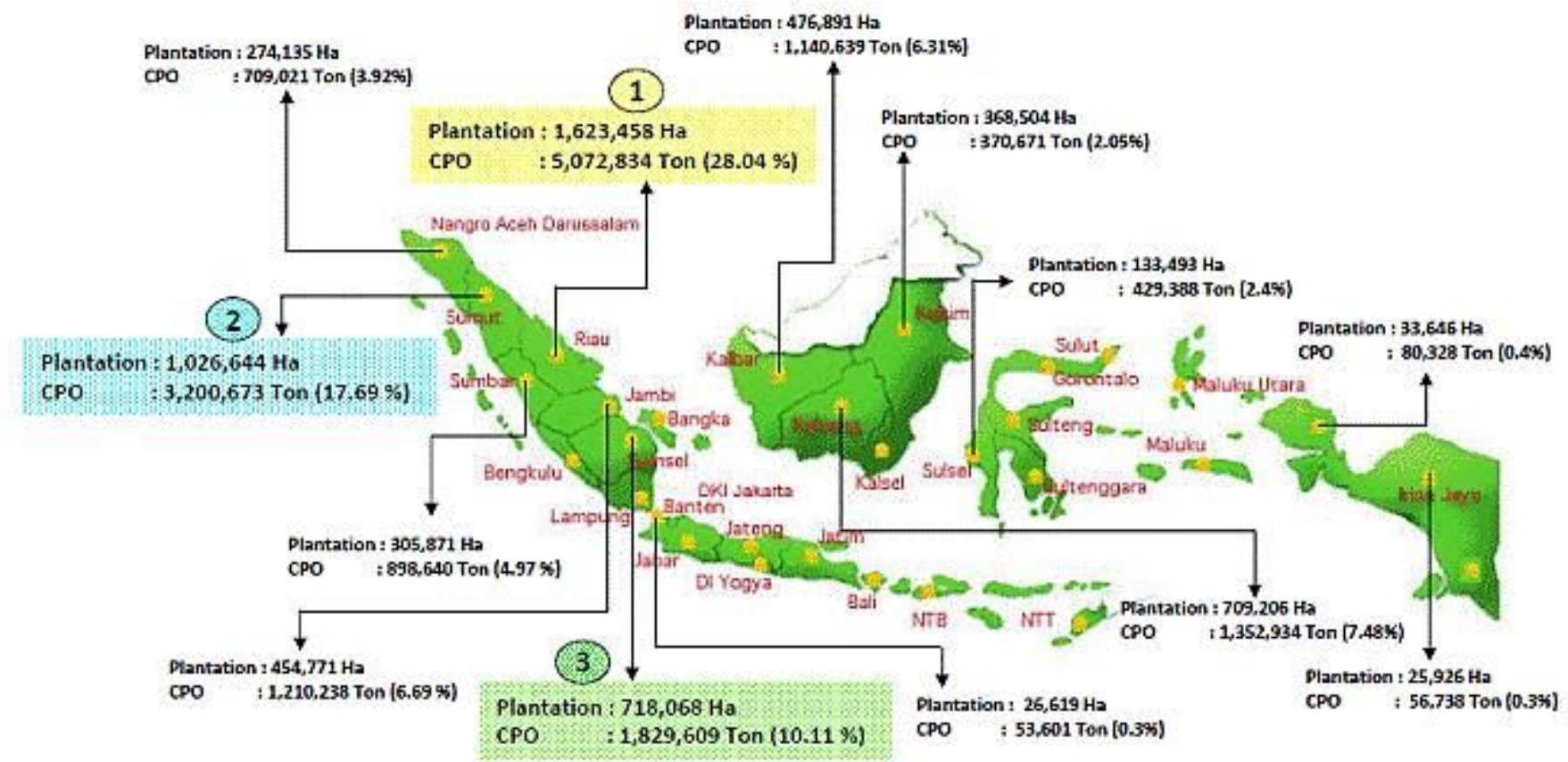

Source: Dept. of Agriculture \& Farestry, indanesia, MPOS

\section{Figure 1}

Distribution of Palm Oil Plantation and Production in Indonesia (InfoSawit 2020) 


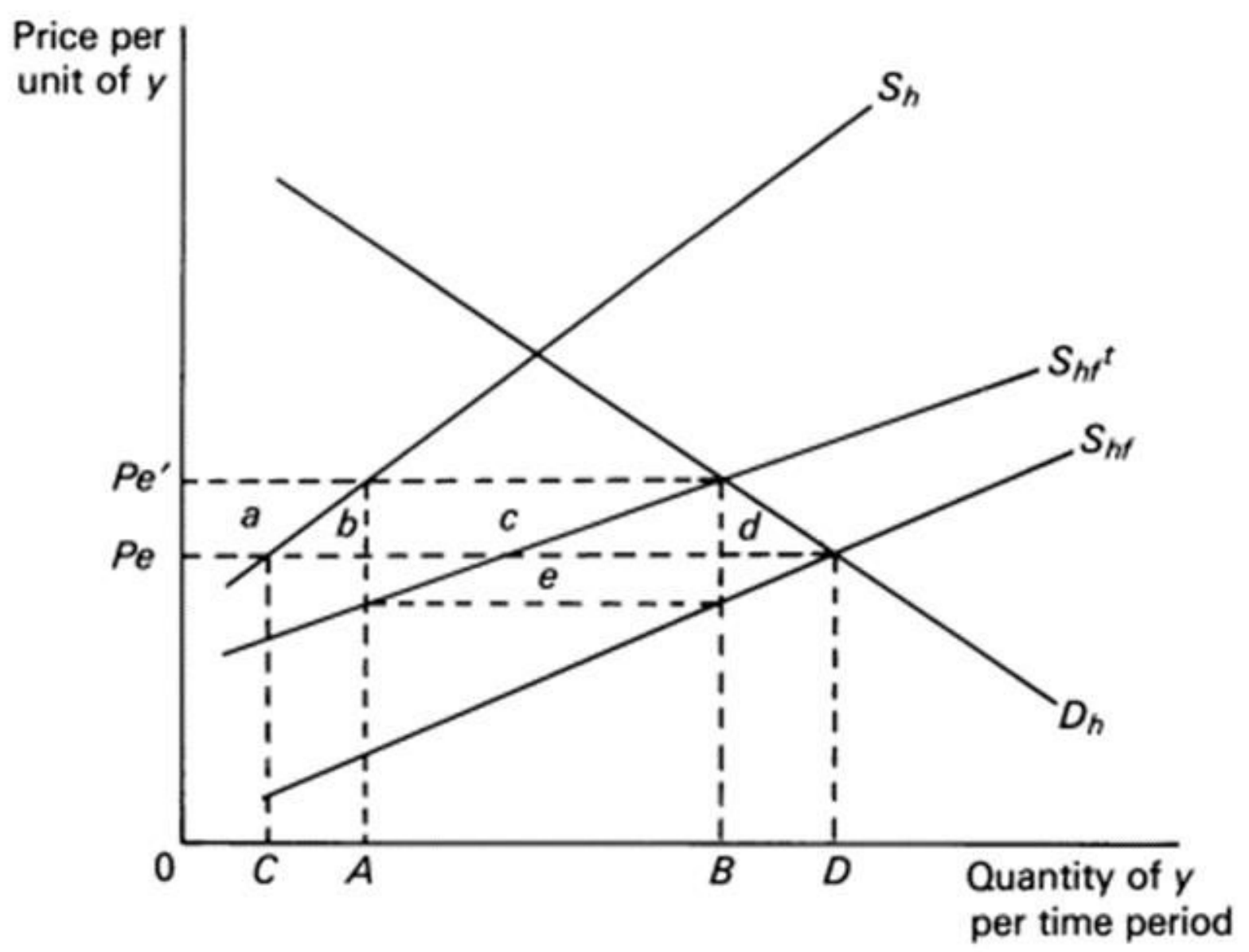

Figure 2

Partial Equilibrium Effect of a Tariff in a Country (Greenaway 1983) Notes: y : a substitute for imported commodity Dh: country's demand for commodity y Sh : country's supply of commodity y Shf : total market supply (domestic supply + imports) Shf t: supply of a tariff-distorted market Pe : the domestic market price of $y$ without tariff burden $\mathrm{Pe}^{\prime}$ : the domestic market price of $\mathrm{y}$ with a nominal tariff rate of $\mathrm{t}$ on all imported y 


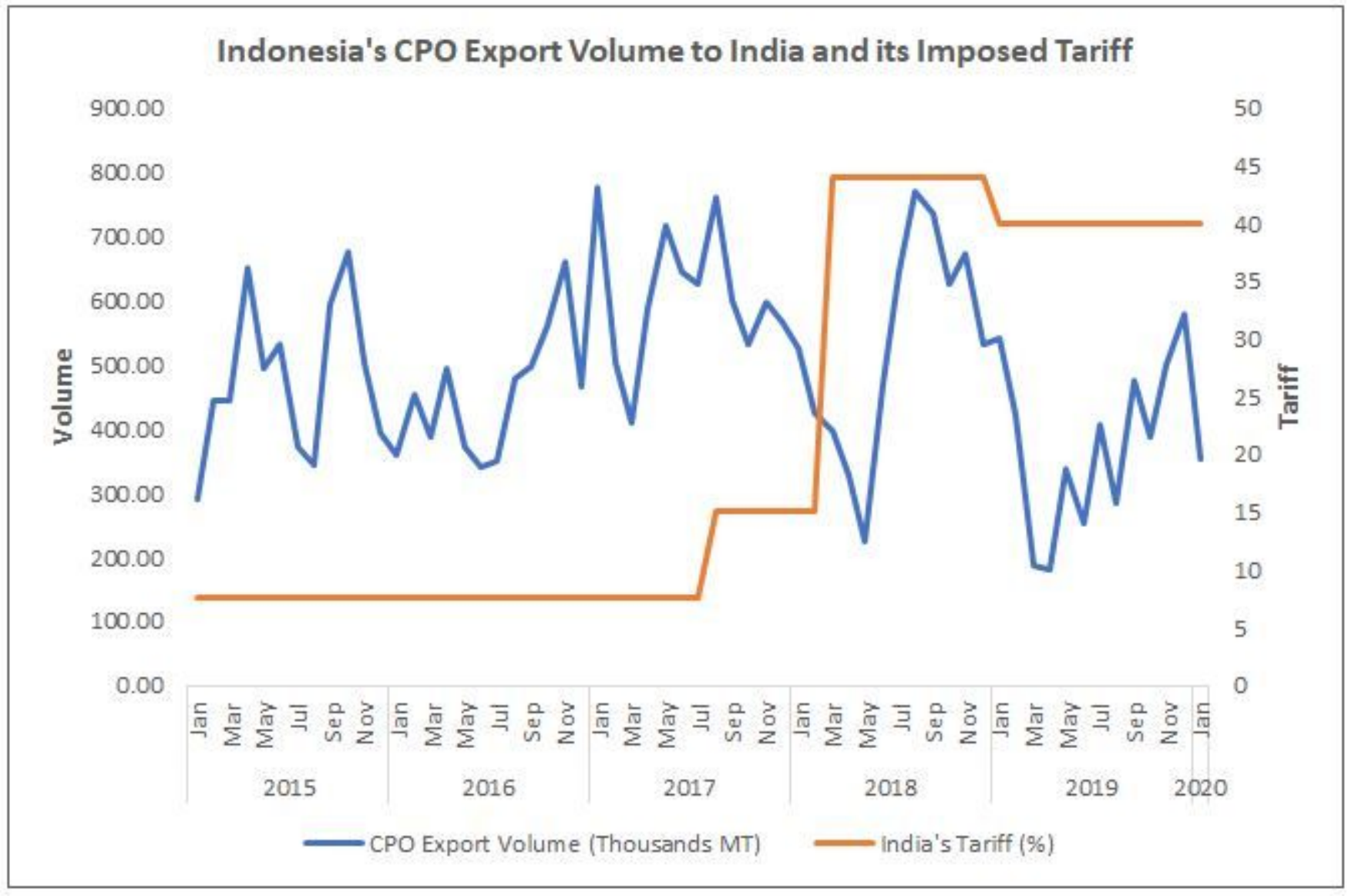

Figure 3

Export volume and tariff (BPS and WTO) 


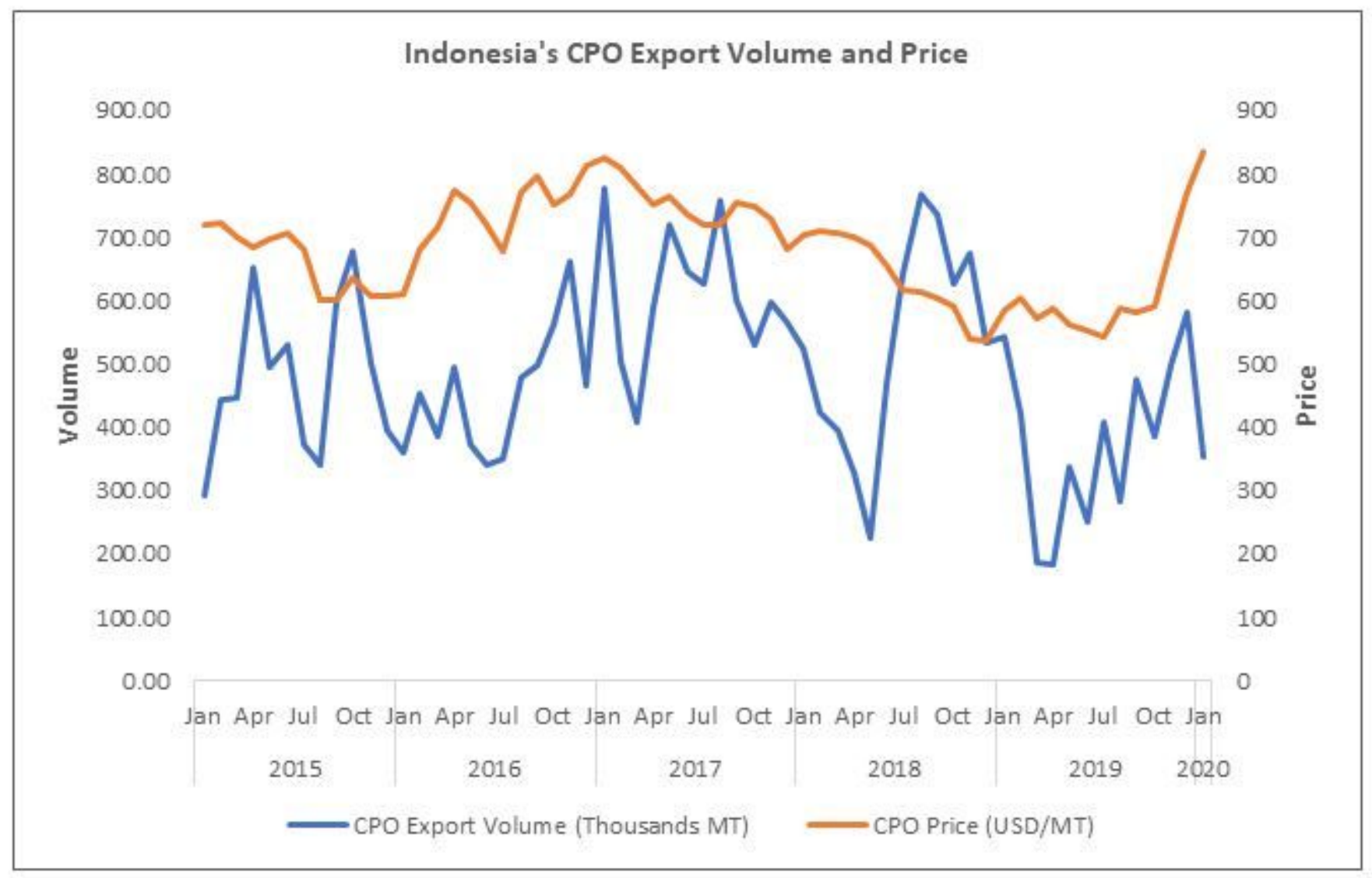

Figure 4

Export volume and CPO Price (BPS, Bloomberg) 


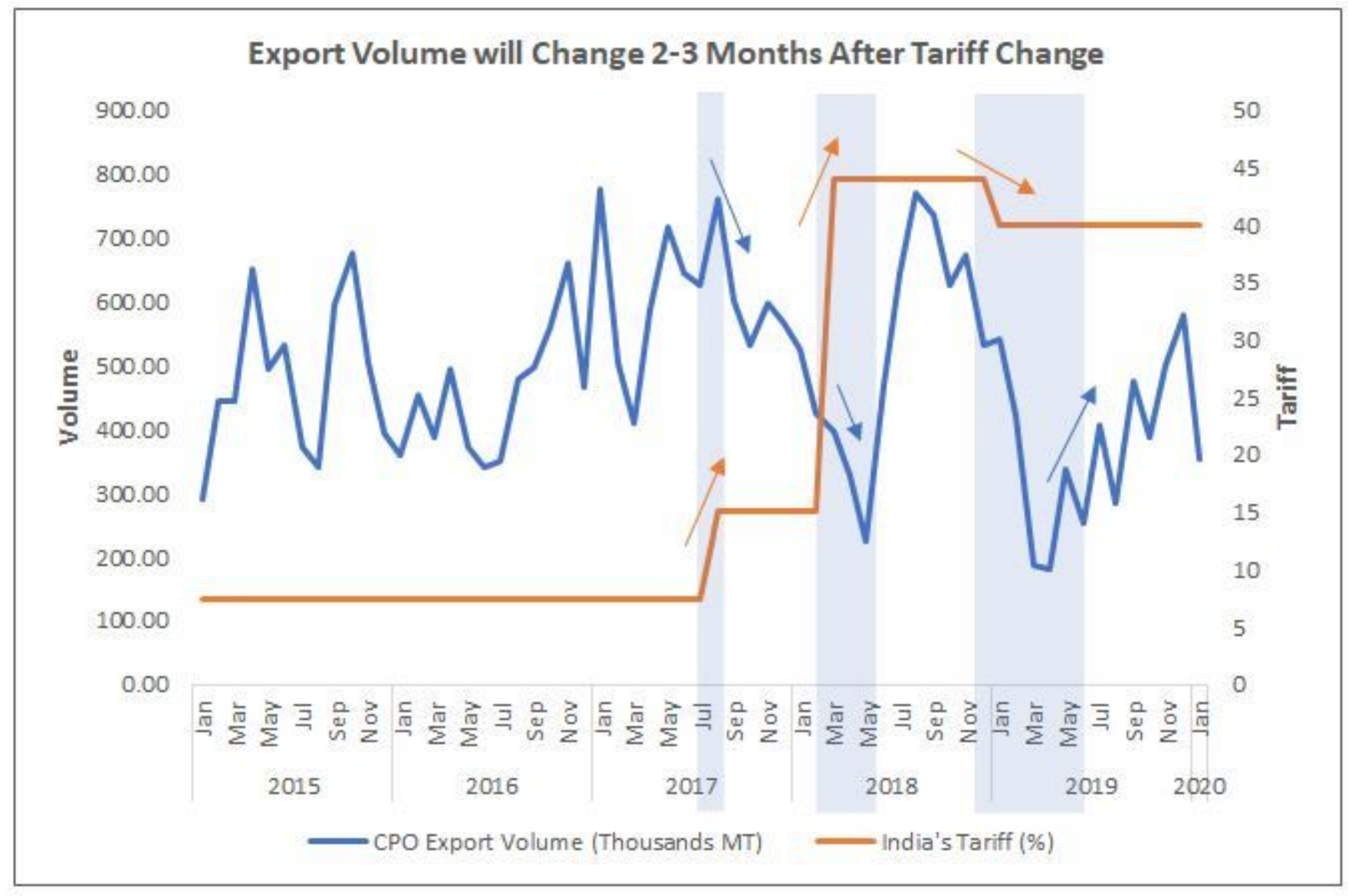

Figure 5

Lag of Export Volume Change Caused by Tariff Change (BPS, WHO) 